Prepared in cooperation with the U.S. Army Corps of Engineers, Omaha District

\title{
Characteristics of Sediment Transport at Selected Sites along the Missouri River during the High-Flow Conditions of 2011
}

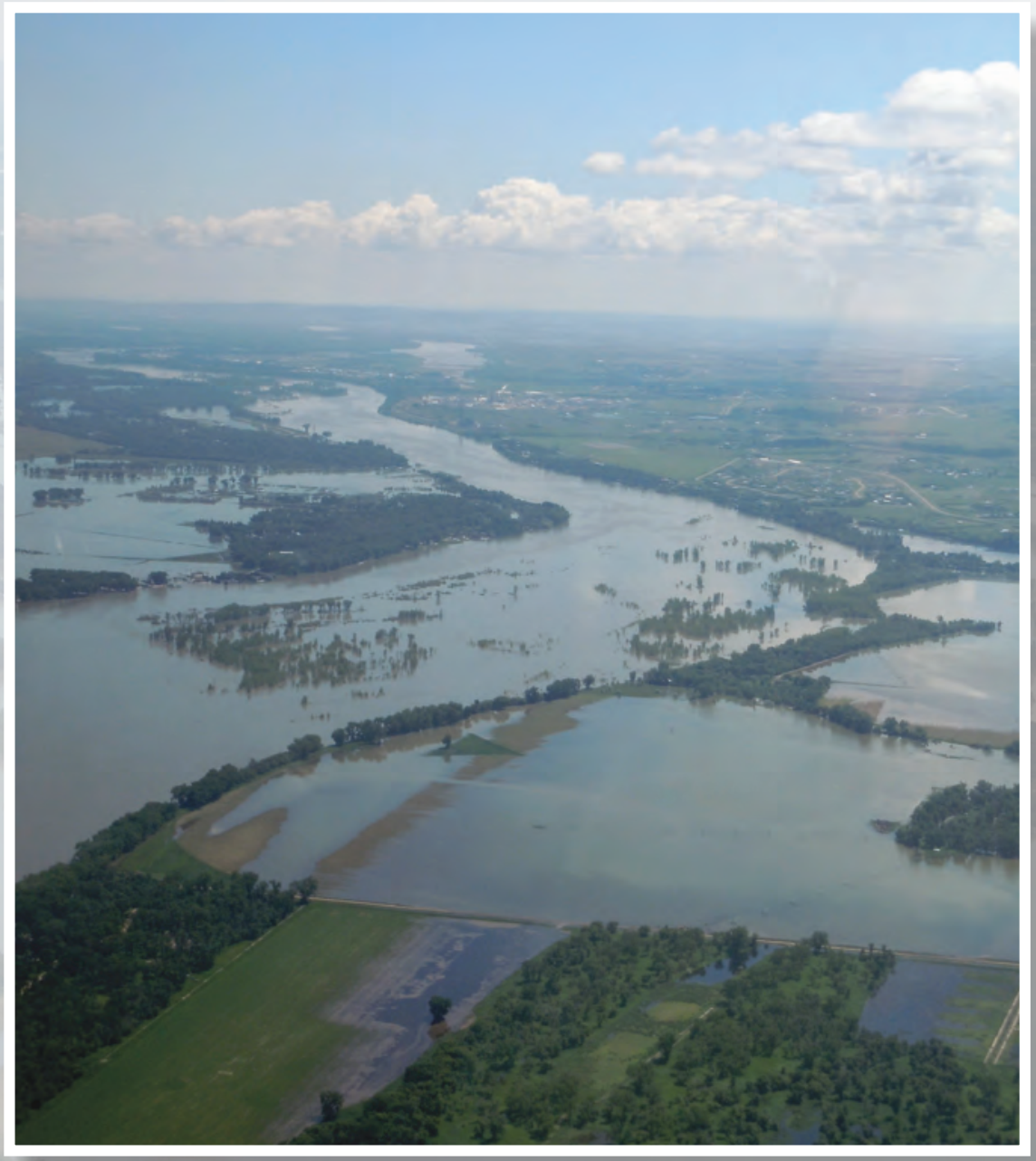

Scientific Investigations Report 2013-5006 
Front cover. Missouri River north of Bismarck, North Dakota, looking downstream, June 23, 2011 (photograph by Joel M. Galloway, U.S. Geological Survey). 


\section{Characteristics of Sediment Transport at Selected Sites along the Missouri River during the High-Flow Conditions of 2011}

By Joel M. Galloway, Dave L. Rus, and Jason S. Alexander

Prepared in cooperation with the U.S. Army Corps of Engineers, Omaha District

Scientific Investigations Report 2013-5006 


\section{U.S. Department of the Interior \\ KEN SALAZAR, Secretary}

\section{U.S. Geological Survey \\ Suzette M. Kimball, Acting Director}

U.S. Geological Survey, Reston, Virginia: 2013

For more information on the USGS - the Federal source for science about the Earth, its natural and living resources, natural hazards, and the environment, visit http://www.usgs.gov or call 1-888-ASK-USGS.

For an overview of USGS information products, including maps, imagery, and publications, visit http://www.usgs.gov/pubprod

To order this and other USGS information products, visit http://store.usgs.gov

Any use of trade, firm, or product names is for descriptive purposes only and does not imply endorsement by the U.S. Government.

Although this information product, for the most part, is in the public domain, it also may contain copyrighted materials as noted in the text. Permission to reproduce copyrighted items must be secured from the copyright owner.

Suggested citation:

Galloway, J.M., Rus, D.L., and Alexander, J.S., 2013, Characteristics of sediment transport at selected sites along the Missouri River during the high-flow conditions of 2011: U.S. Geological Survey Scientific Investigations Report 2013-5006, $31 \mathrm{p}$. 


\section{Contents}

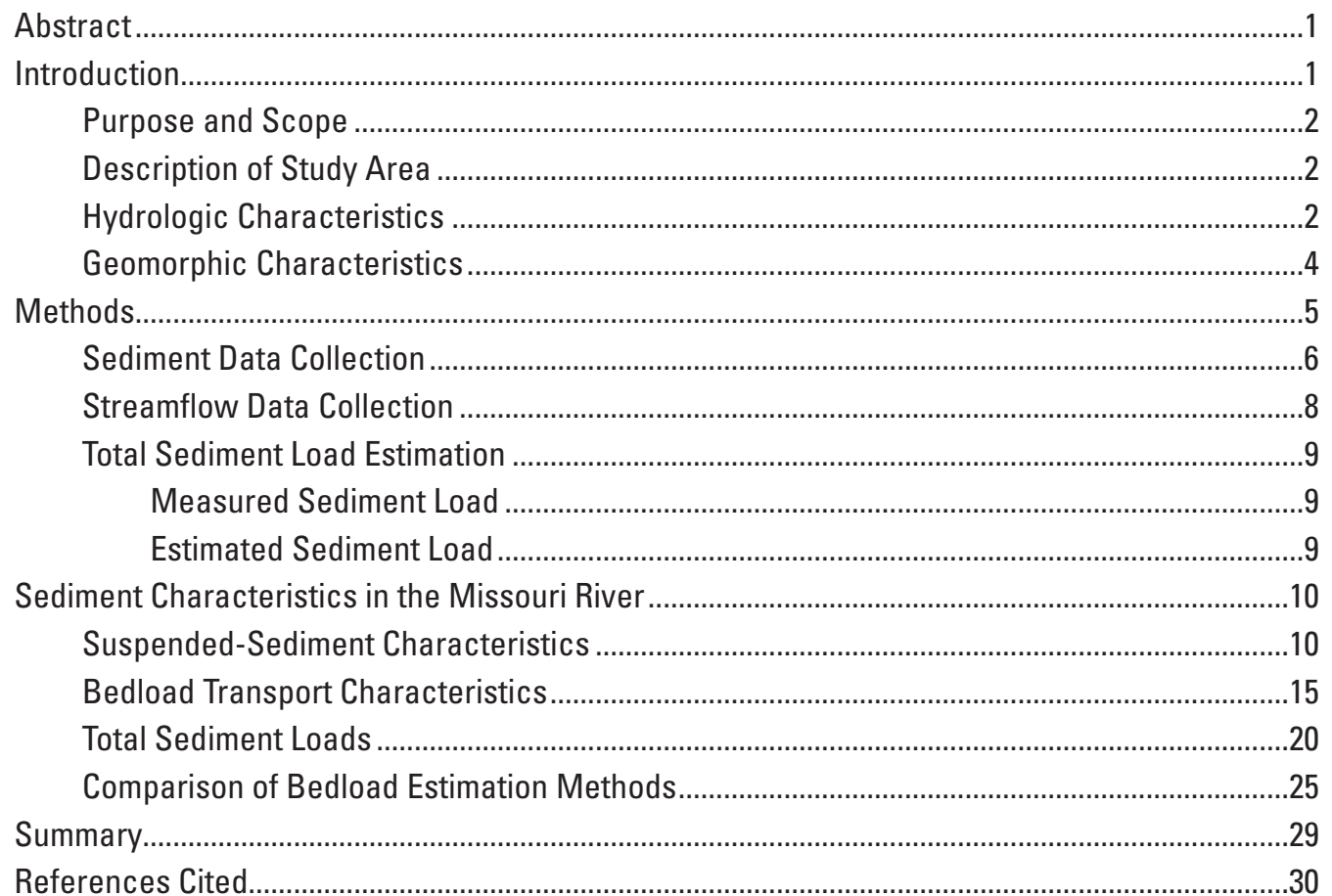

\section{Figures}

1. Map showing location of sediment-sampling sites in the Missouri River Basin...............3

2. Graphs showing daily mean streamflow and sediment sample collection times for six sites on the Missouri River during the 2011 high-flow conditions...........................7

3. Graph showing distribution of suspended-sediment concentrations at six sites on the Missouri River during the 2011 high-flow conditions

4. Graphs showing time series of suspended-sediment concentration, grain-size distribution, and daily mean streamflow for six sites on the Missouri River during the 2011 high-flow conditions.

5. Graph showing distribution of bedload at six sites on the Missouri River during the 2011 high-flow conditions.

6. Graphs showing time series of bedload, grain-size distribution, and daily mean streamflow for six sites on the Missouri River during the 2011 high-flow conditions.

7. Graph showing measured bedload in relation to streamflow for samples collected at six sites on the Missouri River during the 2011 high-flow conditions.

8. Graphs showing time series of total sediment load and daily mean streamflow for six sites on the Missouri River during the 2011 high-flow conditions..

9. Graphs showing sediment loads estimated by the modified-Einstein procedure compared to measured: $A$, total-sediment load; and $B$, bedload 


\section{Tables}

1. Streamflow and sediment data-collection sites on the Missouri River during the 2011 high-flow conditions.

2. Description of terms used to describe sediment characteristics on the Missouri River during the 2011 high-flow conditions.

3. Streamflow, suspended-sediment concentrations, and grain size for six sites on the Missouri River during the 2011 high-flow conditions

4. Grain sizes and mass of bedload samples for six sites on the Missouri River during the 2011 high-flow conditions

5. Sediment loads for six sites on the Missouri River during the 2011 high-flow conditions..

6. Grain sizes of bed-material samples for six sites on the Missouri River during the 2011 high-flow conditions.

\section{Conversion Factors}

\begin{tabular}{lcl}
\multicolumn{1}{c}{ Inch/Pound to SI } & \multicolumn{1}{c}{ Bultiply } & \multicolumn{1}{c}{ To obtain } \\
\hline & Length & \\
\hline inch (in.) & 2.54 & centimeter $(\mathrm{cm})$ \\
inch (in.) & 25.4 & millimeter $(\mathrm{mm})$ \\
foot (ft) & 0.3048 & meter $(\mathrm{m})$ \\
mile (mi) & 1.609 & kilometer $(\mathrm{km})$ \\
\hline & Area & \\
\hline square mile $\left(\mathrm{mi}^{2}\right)$ & 2.590 & square kilometer $\left(\mathrm{km}^{2}\right)$ \\
acre-foot $($ acre-ft) & 1,233 & cubic meter $\left(\mathrm{m}^{3}\right)$ \\
foot per second $(\mathrm{ft} / \mathrm{s})$ & 0.3048 & meter per second $(\mathrm{m} / \mathrm{s})$ \\
cubic foot per second $\left(\mathrm{ft}^{3} / \mathrm{s}\right)$ & 0.02832 & cubic meter per second $\left(\mathrm{m}^{3} / \mathrm{s}\right)$ \\
\hline & Mass & \\
\hline pound, avoirdupois $(\mathrm{lb})$ & 0.4536 & kilogram $(\mathrm{kg})$ \\
ton, short $(2,000 \mathrm{lb})$ & 0.9072 & megagram $(\mathrm{Mg})$ \\
ton per day (ton/d) & 0.9072 & metric ton per day \\
ton per day (ton/d) & 0.9072 & megagram per day $(\mathrm{Mg} / \mathrm{d})$ \\
\hline
\end{tabular}

Vertical coordinate information is referenced to North American Vertical Datum of 1988 (NAVD 88).

Horizontal coordinate information is referenced North American Datum of 1983 (NAD 83).

Concentrations of suspended sediment in water are given in milligrams per liter (mg/L).

Water Year (WY) is defined as beginning October 1 and continuing through September 30 of the following year. 


\title{
Characteristics of Sediment Transport at Selected Sites along the Missouri River during the High-Flow Conditions of 2011
}

\author{
By Joel M. Galloway, David L. Rus, and Jason S. Alexander
}

\section{Abstract}

During 2011, many tributaries in the Missouri River Basin experienced near record peak streamflow and caused flood damage to many communities along much of the Missouri River from Montana to the confluence with the Mississippi River. The large runoff event in 2011 provided an opportunity to examine characteristics of sediment transport in the Missouri River at high-magnitude streamflow and for a long duration. The purpose of this report is to describe sediment characteristics during the 2011 high-flow conditions at six selected sites on the Missouri River, two in the middle region of the basin between Lake Sakakawea and Lake Oahe in North Dakota, and four downstream from Gavins Point Dam along the Nebraska-South Dakota and Nebraska-Iowa borders.

A wider range in suspended-sediment concentration was observed in the middle segment of the Missouri River compared to sites in the lower segment. In the middle segment of the Missouri River, suspended-sediment concentrations increased and peaked as flows increased and started to plateau; however, while flows were still high and steady, suspendedsediment concentrations decreased and suspended-sediment grain sizes coarsened, indicating the decrease possibly was related to fine-sediment supply limitations.

Measured bedload transport rates in the lower segment of the Missouri River (sites 3 to 6) were consistently higher than those in the middle segment (sites 1 and 2) during the high-flow conditions in 2011. The median bedload transport rate measured at site 1 was 517 tons per day and at site 2 was 1,500 tons per day. Measured bedload transport rates were highest at site 3 then decreased downstream to site 5 , then increased at site 6 . The median bedload transport rates were 22,100 tons per day at site $3 ; 5,640$ tons per day at site 4; 3,930 tons per day at site 5; and 8,450 tons per day at site 6 . At the two sites in the middle segment of the Missouri River, the greatest bedload was measured during the recession of the streamflow hydrograph. A similar pattern was observed at sites 3-5 in the lower segment of the Missouri River, where the greatest bedload was measured later in the event on the recession of the streamflow hydrograph, although the change in bedload was not as dramatic as observed at the sites in the middle segment of the Missouri River.

With the exception of site 3, the total-sediment load on the Missouri River was highest at the beginning of the high-flow event and decreased as streamflow decreased. In the middle segment of the Missouri River, measured totalsediment load ranged from 2,320 to 182,000 tons per day at site 1 and from 3,190 to 279,000 tons per day at site 2 . In the lower segment of the Missouri River, measured total-sediment load ranged from 50,600 to 223,000 tons per day at site 4; from 23,500 to 403,000 tons per day at site 5; and from 52,700 to 273,000 tons per day at site 6 .

The total-sediment load was dominated by suspended sediment at all of the sites measured on the Missouri River in 2011. In general, the percentage of total-sediment load that was bedload increased as the streamflow decreased, although this pattern was more prevalent at sites in the middle segment than those in the lower segment. The suspended-sediment load comprised an average of 93 percent of the total load, with the exception of site 3 , where the suspended-sediment load comprised only 72 percent of the total-sediment load.

\section{Introduction}

During 2011, many tributaries in the Missouri River Basin experienced near-record peak streamflow and caused flood damage to many communities along much of the Missouri River from Montana to the confluence with the Mississippi River. The flooding was caused by a combination of above normal snowpack in headwater regions in the Rocky Mountains of Montana and Wyoming, near-record snowfall and wet soil conditions on the plains, and record rainfall in May across the upper Missouri River Basin (Grigg and others, 2012). Total volume of runoff from these conditions into all six Missouri River main stem reservoirs in 2011 was the most since record keeping began, exceeding the previous peak by more than 10 million acre-feet, and forcing releases of record high-magnitude discharges from several of the main 
channel dams operated by the U.S. Army Corps of Engineers (USACE) (Grigg and others, 2012).

The Missouri River is managed by various agencies for multiple purposes, including navigation, flood control, hydropower, water supply, irrigation, fish and wildlife, water quality, and recreation. Sediment transport in the Missouri River is relevant to several of these purposes. Upstream from main stem dams, sedimentation has reduced the water-storage capacity and operational life of reservoirs, and has caused the displacement of at least one riverside community. Downstream from the dams, water releases retain substantial sediment-transport capacity but have lost the natural supply of sediment to reservoir trapping. This disruption of upstream sediment supply has caused bed incision and bank erosion below the dams as the river seeks to satisfy its capacity for sediment transport (Williams and Wolman, 1984; Friedman and others, 1998; Shields and others, 2000; Schmidt and Wilcock, 2008). Channel incision and bank erosion not only threaten infrastructure and private property along the river, but also degrade ecosystem functioning by eroding sandbars and disconnecting the river from flood plain habitats. Finally, much of the lower Missouri River is dredged to maintain a navigable channel as well as for commercial-material extraction, and estimates of sediment transport are necessary for scheduling channel maintenance and permitting purposes.

The large runoff event in 2011 provided an opportunity to examine characteristics of sediment transport in the Missouri River at high-magnitude streamflow and over a long duration. To characterize sediment transport on the Missouri River during the high-flow conditions in 2011, the U.S. Geological Survey (USGS), in cooperation with the USACE, collected sediment samples at selected locations extending from Washburn, North Dakota (N.Dak.) to Nebraska City, Nebraska (Nebr.) (fig. 1).

\section{Purpose and Scope}

The purpose of this report is to describe sediment characteristics during the 2011 high-flow conditions at six selected sites on the Missouri River, two in the middle region of the basin between Lake Sakakawea and Lake Oahe in North Dakota, and four downstream from Gavins Point Dam along the Nebraska-South Dakota and Nebraska-Iowa borders (fig. 1). Sediment samples were collected from June to November at various time intervals among the six sites. The data from the samples were used to provide information on the sediment characteristics of the Missouri River during the high-flow conditions in 2011, including suspended-sediment concentration and grain-size distribution, bedload mass and grain-size distribution, and the transport of sediment in suspension and bedload.

\section{Description of Study Area}

Six sites were selected as locations to measure sediment transport in the Missouri River in 2011 (fig. 1, table 1). Two of these measurement sites were located between Lake Sakakawea and Lake Oahe (hereafter referred to as the "middle segment"), and four were located downstream from Gavins Point Dam (hereafter referred to as the "lower segment") (fig. 1). Locations used for describing segment characteristics refer to the USACE system of river miles, which reference mileage upstream from the confluence with the Mississippi River along the Missouri River channel centerline as it existed in 1960 (Dan Pridal, U.S. Army Corps of Engineers, written commun., 2012).

\section{Hydrologic Characteristics}

Streamflow in the middle segment of the Missouri River is regulated by the Garrison Dam (Lake Sakakawea), which was completed in 1953 (Williams and Wolman, 1984). The mean-annual streamflow at Bismarck, N.Dak. (site 2; USGS streamflow-gaging station number 06342500; fig. 1) from 1953 through 2011 is 22,500 cubic feet per second $\left(\mathrm{ft}^{3} / \mathrm{s}\right)$ (http://wdr.water.usgs.gov). Since completion of the Garrison Dam, and before 2011, the daily maximum streamflow was $68,800 \mathrm{ft}^{3} / \mathrm{s}$ on July 13,1975 . The maximum daily streamflow in 2011 was $154,000 \mathrm{ft}^{3} / \mathrm{s}$ on June 25 (http://wdr.water.usgs. gov). Major tributaries in the middle segment are the Knife and Heart Rivers, which flow into the Missouri River near river mile (RM) 1,374.1 and RM 1,311.1, respectively (fig. 1). Although neither tributary contributes a substantial proportion of the total annual streamflow to the middle segment, these tributaries, in combination with the bed and banks of the Missouri River, are the primary sources of sediment within the segment (Biedenharn and others, 2001); however, the Heart River flows into the Missouri River just downstream from site 2, and therefore does not affect the characteristics of sediment transport described for the sites in this report. The mean-annual streamflow of the Knife River at Hazen, N.Dak. (USGS streamflow-gaging station number 06340500), the furthest downstream measurement station on the Knife River, was the second highest on record in 2011 at $477 \mathrm{ft}^{3} / \mathrm{s}$. Annual peak streamflows at the same station have ranged from 100 to $35,300 \mathrm{ft}^{3} / \mathrm{s}$ over the same period, and the peak streamflow in 2011 reached $6,850 \mathrm{ft}^{3} / \mathrm{s}$ on April 8, a rank of 23rd out of 74 years of record (http://wdr.water.usgs.gov).

Streamflow in the lower segment of the Missouri River is regulated by operations at Gavins Point Dam (Lewis and Clark Lake) as well as inflows from several tributaries (fig. 1). During years when releases from Gavins Point Dam were typical, runoff from tributaries along the lower segment have temporarily constituted a substantial proportion of the total streamflow in the Missouri River. The James River flows into the Missouri River at RM 800.3 between Gavins Point Dam and site 3 (fig. 1). In 2011, the annual-mean streamflow in 


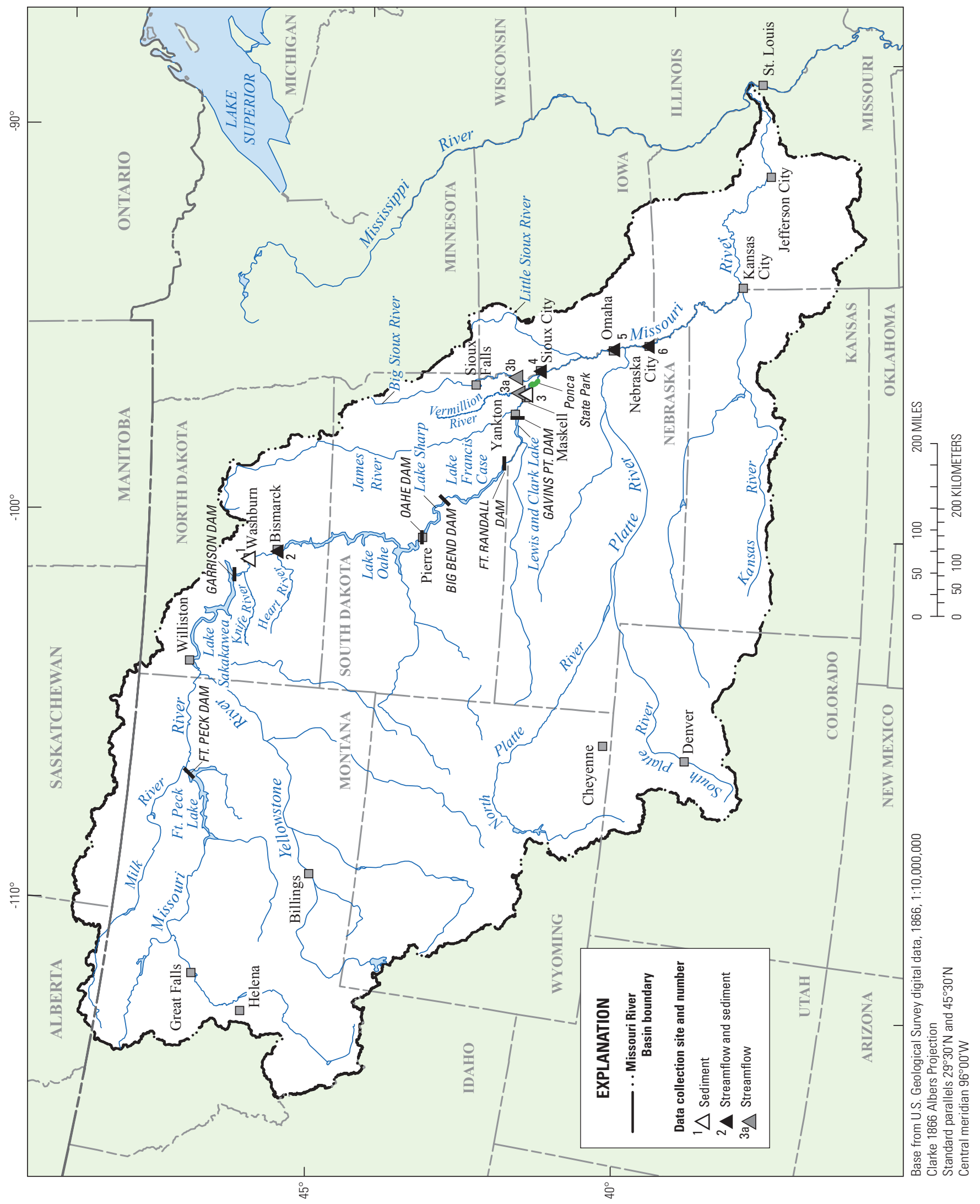

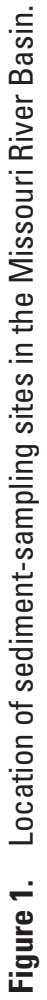


Table 1. Streamflow and sediment data-collection sites on the Missouri River during the 2011 high-flow conditions.

\begin{tabular}{cclc}
\hline $\begin{array}{c}\text { Site } \\
\text { identification } \\
\text { number } \\
\text { (fig. 1) }\end{array}$ & $\begin{array}{c}\text { U.S. } \\
\text { Geological } \\
\text { Survey } \\
\text { station number }\end{array}$ & \multicolumn{1}{c}{ Site description } & Data collected \\
\hline 1 & 0634100 & Missouri River at Washburn, North Dakota & $\begin{array}{c}\text { Sediment } \\
2\end{array}$ \\
206342500 & Missouri River at Bismarck, North Dakota & Streamflow, sediment \\
3 & 06478526 & Missouri River near Maskell, Nebraska & Sediment \\
$3 \mathrm{a}$ & 06485500 & Big Sioux River at Akron, Iowa & Streamflow \\
$3 \mathrm{~b}$ & 06479010 & Vermillion River near Vermillion, South Dakota & Streamflow \\
4 & 06486000 & Missouri River at Sioux City, Iowa & Streamflow, sediment \\
5 & 06610000 & Missouri River at Omaha, Nebraska & Streamflow, sediment \\
6 & 06807000 & Missouri River at Nebraska City, Nebraska & Streamflow, sediment \\
\hline
\end{tabular}

the James River near Yankton, S.Dak. (USGS streamflowgaging station number 06478513 ; record is continuous from 1982 to 1995 and 2010 to 2011) was $6,090 \mathrm{ft}^{3} / \mathrm{s}$, the second highest in the 16 years of record. The peak streamflow at the same station on the James River reached $29,200 \mathrm{ft}^{3} / \mathrm{s}$ on March 28, 2011, but a second rise on July 7 had a daily mean streamflow of $11,400 \mathrm{ft}^{3} / \mathrm{s}$ (http://wdr.water.usgs.gov). The Big Sioux River flows into the Missouri River approximately 6.5 river miles upstream from site 4 at RM 734.2 (fig. 1). In 2011, the annual-mean streamflow in the Big Sioux River at Akron, Iowa (USGS streamflow-gaging station number 06485500 , site $3 \mathrm{a}$ ) was $5,820 \mathrm{ft}^{3} / \mathrm{s}$, the second highest in the 83 years of record from 1929 to 2011. The peak streamflow in the Big Sioux River in 2011 was 19,700 $\mathrm{ft}^{3} / \mathrm{s}$ on March 26, but several additional rises occurred throughout the summer, including a daily mean streamflow of $15,900 \mathrm{ft}^{3} / \mathrm{s}$ on July 18 . Several tributaries flow into the Missouri River between sites 4 and 5. The largest of the tributaries is the Little Sioux River, which flows into the Missouri River near RM 669.3 (fig. 1). In 2011, the annual-mean streamflow in the Little Sioux River near Turin, Iowa (USGS streamflow-gaging station number 06607500) was $3,290 \mathrm{ft}^{3} / \mathrm{s}$, the fifth highest in the 53-year period of record spanning 1959 to 2011. The peak streamflow in water year 2011 at the same site was $13,400 \mathrm{ft}^{3} / \mathrm{s}$ on June 28. The Platte River, which drains an area of 86,000 square miles (Eschner and others, 1983), flows into the Missouri River approximately 33.5 miles upstream from site 6 near RM 595 (fig. 1). The Platte River is the first large tributary to flow into the Missouri River downstream from Gavins Point Dam. In 2011, the annual mean streamflow in the Platte River near Louisville, Nebr. (USGS streamflow-gaging station number 06805500) in 2011 was $11,530 \mathrm{ft}^{3} / \mathrm{s}$, the seventh highest in 58 years of record. The peak streamflow at the same station in 2011 was estimated at 45,400 ft3 3 s. Suspended-sediment loads in the Platte River constitute a substantial proportion of the suspended-sediment load in the Missouri River downstream from the confluence with the Platte River (Heimann and others, 2010).
Since completion of Gavins Point Dam, but before water year 2011, annual-mean streamflow for the Missouri River ranged from 18,700 to $55,900 \mathrm{ft}^{3} / \mathrm{s}$ at site 4 (USGS streamflow-gaging station number 06486000 ); from 20,500 to $62,200 \mathrm{ft}^{3} / \mathrm{s}$ at site 5 (USGS streamflow-gaging station number 06610000 ); and from 25,400 to $66,400 \mathrm{ft}^{3} / \mathrm{s}$ at site 6 (USGS streamflow-gaging station number 06807000) ( $h t t p: / / w d r$. water.usgs.gov). In water year 2011, annual-mean streamflow measured at these sites were $79,100 \mathrm{ft}^{3} / \mathrm{s} ; 86,400 \mathrm{ft}^{3} / \mathrm{s}$; and $96,700 \mathrm{ft}^{3} / \mathrm{s}$, respectively. Since completion of Gavins Point Dam, but before 2011, annual-peak streamflow in the Missouri River ranged from 32,700 to $104,000 \mathrm{ft}^{3} / \mathrm{s}$ at site $4 ; 41,400$ to $120,000 \mathrm{ft}^{3} / \mathrm{s}$ at site 5 ; and 47,900 to $196,000 \mathrm{ft}^{3} / \mathrm{s}$ at site 6 . In 2011, estimated instantaneous peak streamflow at these sites were $192,000 \mathrm{ft}^{3} / \mathrm{s} ; 217,000 \mathrm{ft}^{3} / \mathrm{s}$; and 229,000 ft $\mathrm{ft}^{3} / \mathrm{s}$, respectively (http://wdr.water.usgs.gov).

\section{Geomorphic Characteristics}

River channel width in the middle segment of the Missouri River ranges from approximately 400 to 4,500 feet (ft), and averages approximately 2,000 ft (Biedenharn and others, 2001). Williams and Wolman (1984) reported that, in general, the bed of the Missouri River degraded in the years following closure of Garrison Dam, and reported changes in mean-bed elevation ranging from -10.7 to 0.65 feet in the 54 miles below the dam between 1954 and 1976; however, the rate of channel bed degradation slowed substantially by 1976 , and a more recent study by Biedenharn and others (2001) indicated the river bed is approaching a state of dynamic equilibrium.

The lower segment of the Missouri River can be broadly divided into two distinct geomorphologic reaches. Between Gavins Point Dam (RM 811) and Ponca State Park, Nebr. (RM 753), the Missouri River is unchannelized (hereafter referred to as the "unchannelized reach"), has numerous mid-channel sandbars and islands, and a high bank-migration rate (Elliott and Jacobson, 2006). Average bank-to-bank channel width in the unchannelized segment is approximately $2,850 \mathrm{ft}$, but ranges from approximately 660 to $6,020 \mathrm{ft}$. Sinuosity across 
the unchannelized reach was estimated at 1.10 in 1999 (Elliott and Jacobson, 2006). Downstream from Ponca State Park (hereafter referred to as the "channelized reach"), the Missouri River has been channelized by wing dikes, sills, and bank revetments that have created a generally uniform, trapezoidal channel. Bank-to-bank channel width in the channelized reach varies from approximately 600 to $1,000 \mathrm{ft}$ along the entire 753 miles to the confluence with the Mississippi River near St. Louis, Missouri (Mo.) (National Research Council, 2002). Sinuosity in the channelized reach is higher than in the unchannelized reach, averaging 1.42 in 1999 between Ponca State Park and Sioux City, Iowa (site 4), and likely is similar in the reaches downstream from Sioux City (Elliot and Jacobson, 2006).

Streambed elevations in the lower segment were declining before closure of the system of reservoirs upstream, but the rate of incision accelerated after closure of Gavins Point Dam in 1955 (Williams and Wolman, 1984; Jacobson and others, 2009). Within the first 11 miles below Gavins Point Dam, the river streambed elevation has decreased, on average, by $11.5 \mathrm{ft}$, and averages as much as $6 \mathrm{ft}$ in the reaches downstream to Ponca State Park (Elliot and Jacobson, 2006). Streambed-incision rates in the channelized segment are highest at the upstream end, and generally decrease in the downstream direction. At site 4, the streambed elevation has decreased by as much as $16 \mathrm{ft}$ since closure of Gavins Point Dam, but this magnitude decreases to approximately $6 \mathrm{ft}$ at site 5 (Jacobson and others, 2009), and is minor at site 6 (fig. 1) (Chen and others, 1999).

Characteristics of sediment transport at a given site largely are a function of the quantity and grain size of

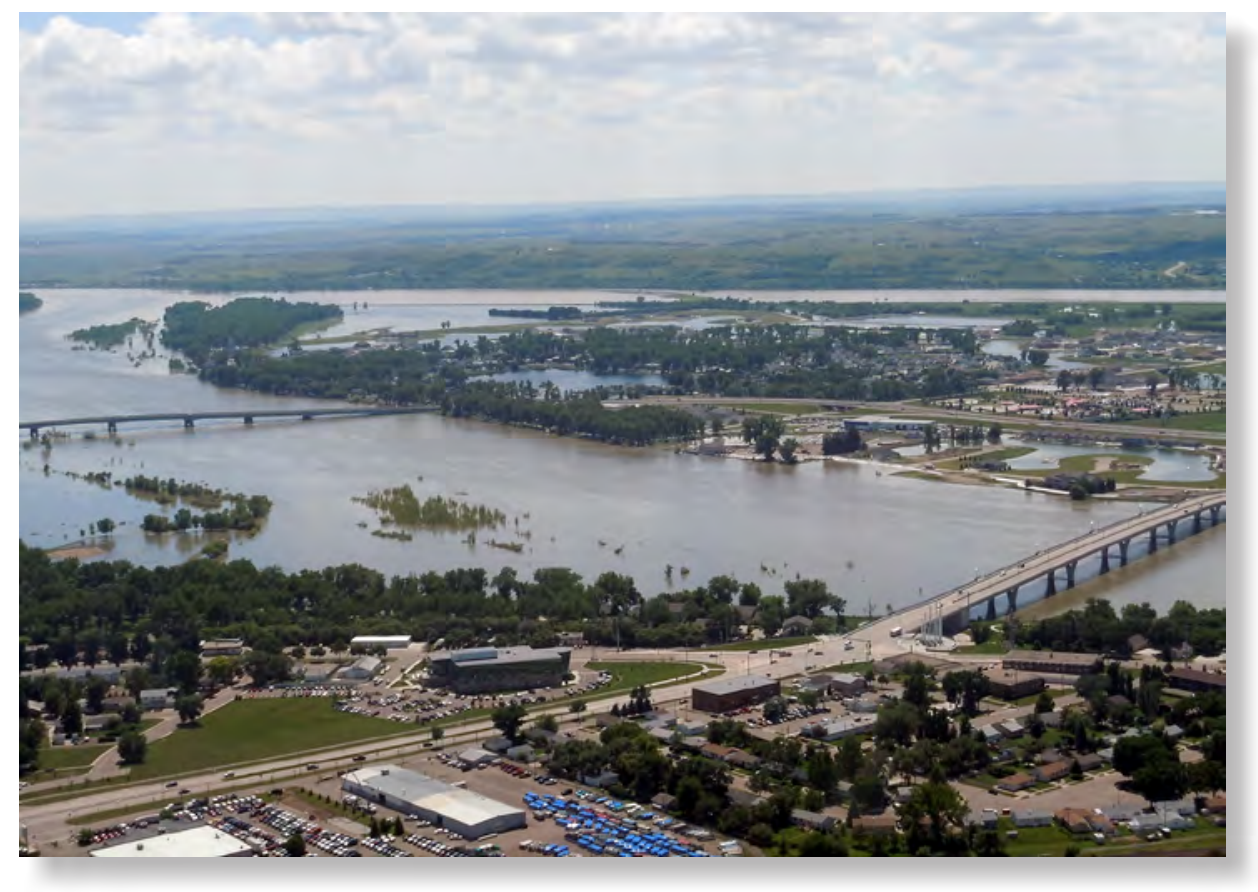

Missouri River at Bismarck, North Dakota (site 2), June 23, 2011. Samples were collected from bridge on right side of photograph (photograph by Joel M. Galloway, U.S. Geological Survey). sediment available for transport locally from the streambed or banks, the quantity and grain size of sediment supply being delivered from upstream or from nearby tributaries, and the local hydraulic conditions that dictate the transport capacity of the streamflow. Variations in channel-hydraulic geometries can cause changes in hydraulic conditions for a constant flow over short distances. Ideally, hydraulic geometries at measurement sites would be representative of the broader segment-scale hydraulic geometries. In practice, streamflow-gaging stations are often located near bridges. These bridges provide convenient and safe stationary platforms for measuring sediment transport, and the streamflow information can be used to make estimates of sediment load; however, bridges also can alter local hydraulic geometries, especially during high-flow conditions. Thus, not all sites chosen for measurement necessarily are representative of their broader segment-hydraulic geometries but, by continuity, would be expected to be transporting roughly the same total mass of sediment as adjacent reaches.

\section{Methods}

The following sections describe methods used for the assessment of sediment transport during the 2011 high-flow conditions in the Missouri River. Generally, sediment transport was estimated from measurements of streamflow, suspendedsediment concentration (SSC), bedload, and bed-materialgrain-size distributions. Data were collected by the USGS at two sites in the reach of the Missouri River between Lake Sakakawea and Lake Oahe in North Dakota (sites 1 and 2) and at four sites downstream from Gavins Point Dam along the Nebraska border, including one in the unchannelized reach (site 3), and three in the channelized reach (sites 4-6; fig. 1).

This report uses a series of terms to characterize sediment transport by quantifying sediment load grouped according to a measurement-principle or transport mechanism (Church, 2006). Terms used to describe the measurement principle include suspended-sediment load, bedload, and bed material (table 2). Terms used to describe the transport mechanism include bed-material load, wash load, and total-sediment load (table 2).

In general, most measurements were made from bridges near existing USGS streamflow-gaging stations. The collection of bedload samples by boat during the high-flow conditions was deemed dangerous and prone to measurement error caused by boat movement during sampling; 
Table 2. Description of terms used to describe sediment characteristics on the Missouri River during the 2011 high-flow conditions.

[Descriptions used in this table were derived from Church (2006), and Edwards and Glysson (1999)]

\begin{tabular}{cc}
\hline Term & Description \\
\hline Suspended-sediment load & $\begin{array}{c}\text { Component of sediment load consisting of particles that move in a downstream direction by suspension } \\
\text { within the water column; operationally, it is the component of sediment transport spanning the water } \\
\text { surface down to a depth associated with the unsampled zone of the sampler. } \\
\text { Component of sediment transport consisting of particles that move in a downstream direction by rolling, } \\
\text { saltating, or bouncing along the riverbed or the component of sediment in transport from the surface of } \\
\text { the riverbed up to the height of the top of the sampler nozzle. } \\
\text { Sediment particles on the surface of the bed of the river and below the surface down to a depth equal to the } \\
\text { radius of the trap door of the sampling device. }\end{array}$ \\
Bed material & Transport mechanism \\
\hline Bed-material load & $\begin{array}{c}\text { Component of sediment load consisting of grain sizes finer than that represented in the bed, and therefore } \\
\text { constrained to being measured in the suspended-sediment sample. } \\
\text { Component of sediment load (whether measured as bedload or in suspension) that consists of grain sizes } \\
\text { represented in the streambed. } \\
\text { Sum of bedload and suspended-sediment load. }\end{array}$ \\
\hline
\end{tabular}

however, suspended-sediment and streamflow measurements were collected by boat at sites $4-6$ as part of a data-collection program done in parallel to this study. With the exception of one sample (site 6 on June 27 and 28), suspended-sediment and bedload measurements occurred on the same day. With the exception of site 5 , measurements were made within the same reach of the Missouri River. At site 5, measurements of suspended sediment were made by boat near U.S. Interstate 480 (I-480) at RM 616. Because of safety concerns associated with heavy traffic on the I-480 Bridge, measurements of bedload and bed material were made roughly 10.4 river miles upstream at the U.S. Interstate 680 (I-680) Bridge at RM 626.4, which was closed to the public during the sampling period. Unfortunately, hydraulic conditions were quite different at the two measurement locations in 2011. At the I-680 Bridge, the wetted width of the river spanned most of the valley bottom and attained a width of over 4 miles during the peak of the flood, but measurements of bedload were limited to the main channel under the bridge, which contained most of the floodflow. In contrast, all of the floodflow in the river near the I-480 Bridge was confined to the main channel by levees and was approximately 0.2 miles wide. Although most of the streamflow at the I- 680 Bridge was located within the 0.2 mile-wide channel under the bridge, there likely was more hydraulic energy at the I- 480 Bridge. Consequently, some sediment particles that were transported as bedload at the I-680 Bridge may have gone into suspension once reaching the area near the I-480 Bridge. Therefore, total-sediment transport estimates at site 5 may be positively biased as a result of the double-accounting of these particles.

\section{Sediment Data Collection}

Suspended-sediment, bed material, and bedload samples were collected at six sites on the Missouri River at various time intervals during the 2011 high-flow conditions. In general, suspended-sediment, bedload, and bed-material samples were collected more often during the peak and recession of the streamflow hydrograph than during the rise of the streamflow hydrograph at each site (fig. 2).

Because of practical considerations, samples were collected from the main channel of the river and did not include the portion of streamflow or sediment load associated with flood-plain-overbank flow at sites 3-6. It is likely that sediment-transport conditions outside of the main channel were substantially different than the main channel; however, the effect of this potential difference only likely affected samples collected at sites 5 and 6 and only during the highest streamflow conditions at those sites.

Suspended-sediment samples were collected to estimate the amount of suspended material that was being transported past the six sites during the event. To collect samples that represent the vertical and horizontal variability of suspended sediment in the stream channels, samples were collected isokinetically (velocity enters the sampler nozzle at the same velocity of the stream) using depth-integrated samplers (Davis, 2005) at multiple locations along a transect. Different collection methods for suspended sediment were used at different sites because data were collected as part of a previously established data-collection program at sites 4-6. In most cases, a US D-96 bag sampler (Davis, 2005) was used to collect the suspendedsediment sample. For samples collected before July 20, 2011, at sites 4-6, a US P-61 (Davis, 2005) was used, which normally is used for collecting a sample at a discrete point, but can be used in depth-integrated sampling if the nozzle is 

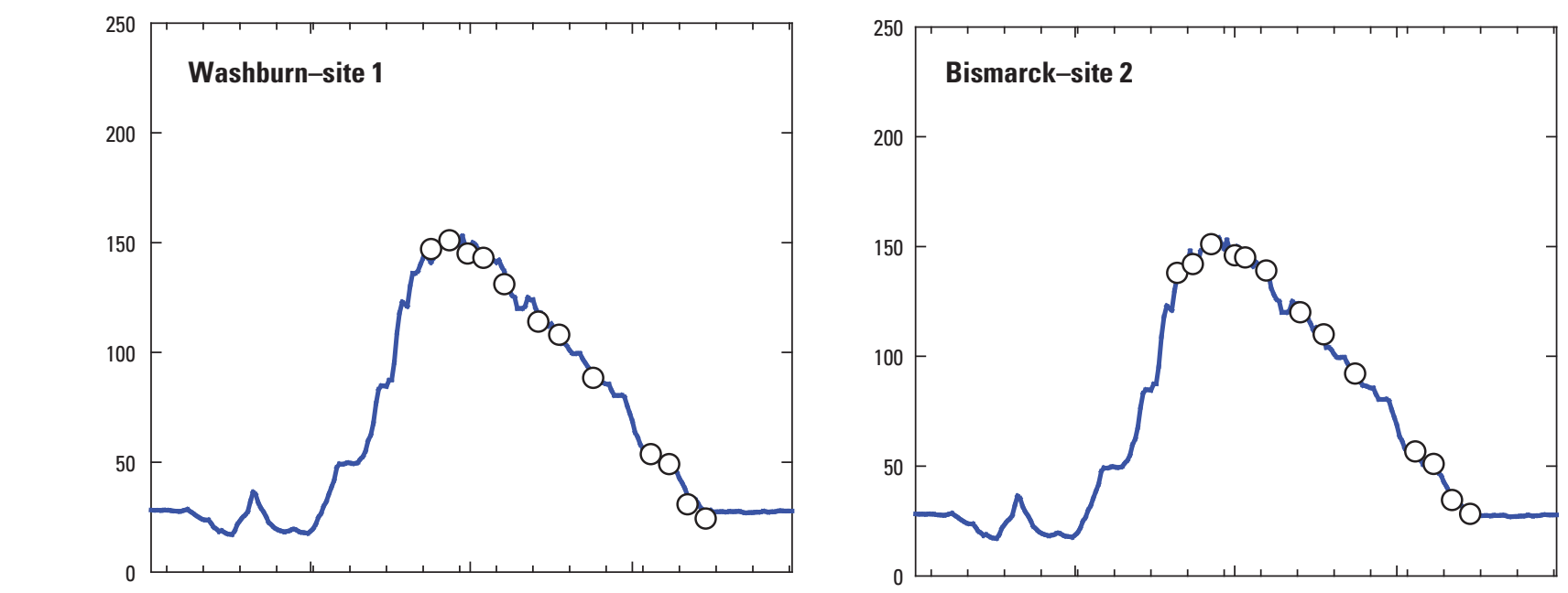

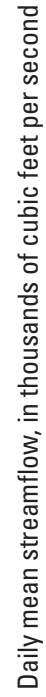
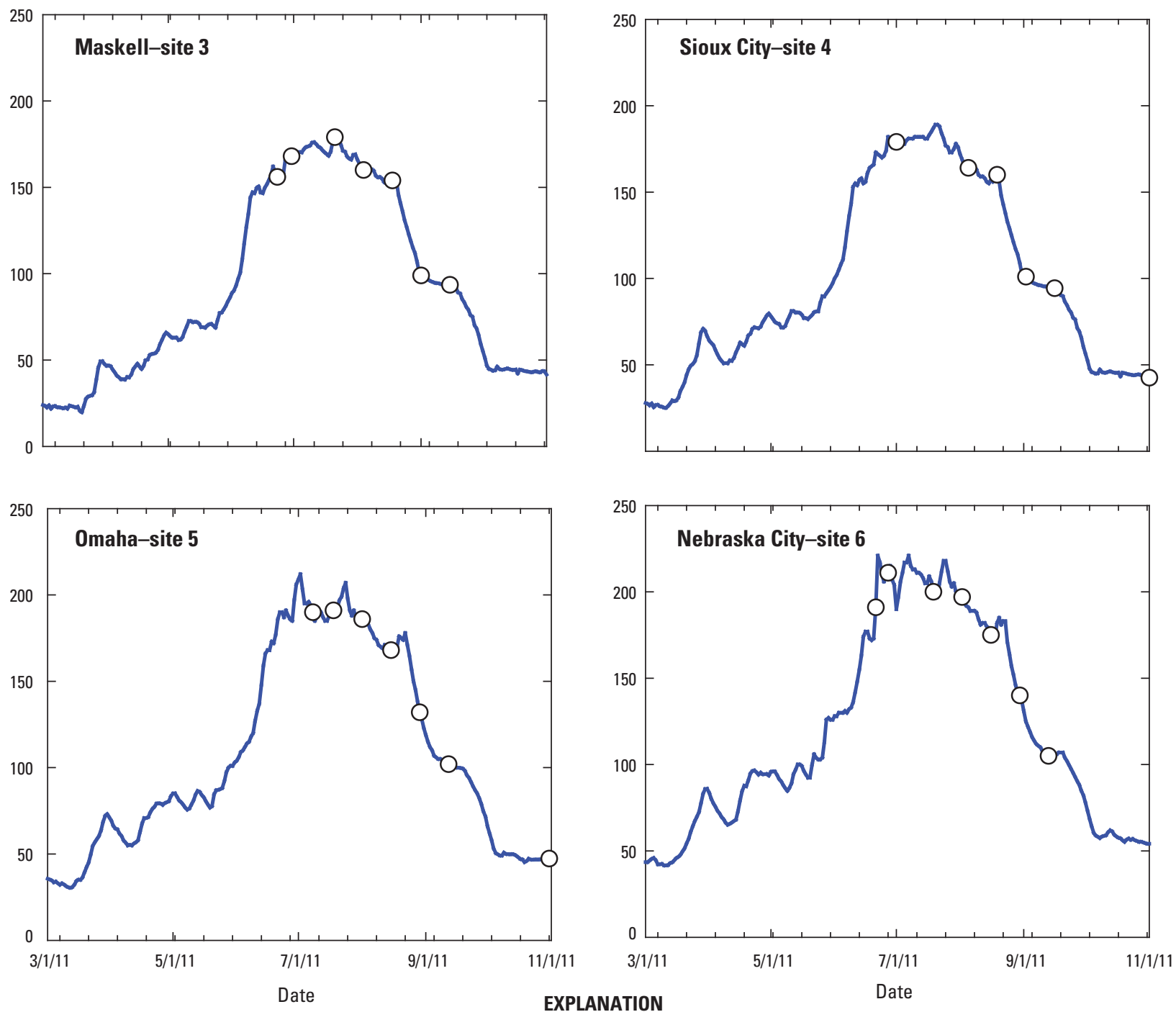

XPLANATION

Daily mean streamflow

Sample collected

Figure 2. Daily mean streamflow and sediment sample collection times for six sites on the Missouri River during the 2011 highflow conditions. 
left in the open position throughout the sample (Edwards and Glysson, 1999). Samples were collected at 10 intervals with equal widths in the transect, called the equal-width increment (EWI) sampling method (Edwards and Glysson, 1999), at sites 1-3. Samples were collected at three intervals in the transect that represented equal streamflow increments, called the equal discharge increment (EDI) method, at sites 4-6. Samples collected using the EWI method (at sites 1-3) were composited in a plastic churn splitter and processed into 1-liter plastic bottles. For samples collected using the EDI method (at sites 4-6), samples associated with the individual verticals were submitted separately for laboratory analysis, at which time they were composited. In many cases at all of the sites, the suspended-sediment sample did not include the water column from 0.5 to $2 \mathrm{ft}$ above the bottom of the streambed to avoid the potential for compromising of the sample by bed material, which often occurs when the sampler is lowered all the way to the streambed.

Several replicate samples were collected at sites 1 and 2 . Replicate samples were obtained for SSC samples by splitting a representative volume of water from the churn splitter concurrently with the regular sample. Five replicate samples were collected; three at site 1 and two at site 2 . The replicate SSC were within 9 and 32 percent of the SSC for the regular samples. Given the extreme high-flow conditions and high amount of sand-sized particles in suspension in the samples, the results were considered acceptable.

Bed-material samples were collected using a US BM-54 sampler (Davis, 2005). The bed-material samples were collected at five equally spaced verticals in the stream cross section and composited for analysis. Four bed-material samples (two each from sites 5 and 6 ) were not collected as a result of sampler malfunctions.

Bedload samples were collected to estimate the sediment transport near the streambed at the six sites. Bedload samples were obtained using a Helley-Smith Model 8035 sampler (at sites 1 and 2) or a BL-84 (sites 3-6) (Davis, 2005) suspended from a cable by a crane. The samplers are designed for orientation in the direction of flow when deployed on the streambed. Bedload samples were collected at 20 equal-width sections across the stream cross section. At sites 1 and 2, sediment masses from each vertical were composited before being weighed. At sites 3-6, the twenty equal sections were sampled in two sequential passes across the bridge for every sample.

Initially, the sediment masses from each vertical were weighed separately; however, the final estimate of bedload was derived by compositing the sediments from each vertical and both passes before being weighed. The composited sediments were then subsampled for sieve analysis.

The hydraulic conditions of the Missouri River in 2011 likely exceeded the operational range of the Helley-Smith and BL-84 bedload samplers. Critical for the proper collection of bedload at any given vertical is that the sampler comes to rest on the streambed with no forward velocity, that the sampler remains stationary during collection, and that, in lifting the sampler off the streambed, it does not maintain contact with the streambed (such as might occur with the lee side of a dune). Violation of these conditions may lead to the dredging of bed material that may not be part of the bedload; however, the hydraulic conditions of the Missouri River in 2011 challenged these criteria with depths exceeding 50 feet (at sites in the lower segment) and stream velocities frequently exceeding 10 feet per second. Before collecting the first sample, the collection procedures were refined so as to gain as much confidence as possible that the criteria were being met. This included the addition of as much as 75 pounds of weight to the sampler (using sounding weights affixed above the sampler), the lowering of the sampler as quickly as the equipment would allow (typically at a downward rate of 4 to 5 feet per second), the maintenance of slack cable during the sampling period (to the extent possible given the hydraulic conditions), and the retrieval of the sampler as quickly as the equipment would allow (typically 3 to 5 feet per second). Without any means of visually observing the behavior of the sampler on the bed of the river, the effectiveness of these techniques is only presumed. In addition, the temporal variation in bedload at a given vertical will increase as the sampling time on the streambed becomes small relative to the cycle period of the dune being measured (Edwards and Glysson, 1999). Because of the limitations of the sampler volume, the samplers typically were left on the streambed for 40 seconds or less at individual stations, which is assumed to be 5 percent or less of the dune period.

All suspended-sediment samples were analyzed for concentration and grain-size distribution at the USGS Iowa Water Science Center Sediment Laboratory in Iowa City, Iowa using methods described in Guy (1969). Bed material and bedload samples were analyzed for grain-size distribution at the same laboratory using the methods described in Guy (1969). Results from the laboratory analysis were stored in the USGS National Water Information System (NWIS) database (http://nwis. waterdata.usgs.gov/nd/nwis/qw).

\section{Streamflow Data Collection}

Streamflow data were important for understanding the hydraulic conditions of the river and the resulting potential sediment-transport capacity of the river channel. Streamflow measurements were made concurrently with most of the sediment samples collected at the six sites. Streamflow was measured using an acoustic Doppler current profiler (ADCP) with the methods and procedures described in Mueller and Wagner (2009). Measurements that included flooded-overbank areas were revised such that the resulting streamflow data corresponded only to the area where sediment transport measurements were being made.

In addition to the discrete measurements, continuousstreamflow data were available at sites 2, 4, 5, and 6 (table 1, fig. 1). Streamflow data were stored in the USGS NWIS database (http://nwis.waterdata.usgs.gov/nd/nwis/). Streamflow data from site 2 were used to estimate streamflow for the 
computation of sediment loads at site 1. Continuous streamflow for site 3 was estimated by subtracting the daily mean streamflow for the Big Sioux River (Big Sioux River at Akron, Iowa, USGS streamflow-gaging station number 06485500 , site 3a; fig. 1 and table 1 ), and the Vermillion River (Vermillion River near Vermillion, S. Dak., USGS streamflow-gaging station number 06479010, site 3b; fig.1 and table 1) from the daily mean streamflow at site 4 (USGS streamflow-gaging station number 06486000).

\section{Total Sediment Load Estimation}

One of the most difficult problems encountered in openchannel hydraulics is the determination of the rate of movement of bed material (bed-material load; table 2) (Einstein, 1950), but an estimate of total-sediment load could be underestimated if bed-material load is neglected. Two methods were used to estimate the total-sediment load at each site. The first was simply the sum of sampled rates of suspended sediment and bedload sediment. The second involved a computational estimate derived from the modified-Einstein procedure of Colby and Hembree (1955).

\section{Measured Sediment Load}

The measured total-sediment load was computed as the sum of the measured suspended-sediment load and bedload. Suspended-sediment loads were estimated for the six sites using estimated or measured daily mean streamflow data and measured SSC data (equation 1; Porterfield, 1972) collected at each site in 2011:

$$
Q_{s}=Q_{w} x C_{s} x K_{s}
$$

where

$$
\begin{aligned}
& Q_{s} \quad \text { is the suspended-sediment load, in tons } \\
& \text { (English short tons) per day (tons/day); } \\
& Q_{w} \quad \text { is the daily mean streamflow, in cubic feet per } \\
& \text { second }\left(\mathrm{ft}^{3} / \mathrm{s}\right) \text {; } \\
& C_{s} \quad \text { is the SSC, in milligrams per liter }(\mathrm{mg} / \mathrm{L}) \text {; and } \\
& K_{s} \text { is a coefficient (0.0027) to convert the units of } \\
& \text { measurement of streamflow and SSC into } \\
& \text { tons/day and assumes a specific gravity of } \\
& \text { sediment of } 2.65 \text {. }
\end{aligned}
$$

The bedload component was calculated from the measured data using equation 2 (Edwards and Glysson, 1999):

$$
Q_{b}=K_{b} \times\left(W_{T} / t_{T}\right) \times M_{T}
$$

where

$$
\begin{array}{ll}
Q_{b} & \text { is the bedload in tons/day; } \\
K_{b} & \text { is a conversion factor (0.381 for a 3-inch wide } \\
& \text { nozzle); } \\
W_{T} & \text { is the total width of the stream from which } \\
& \text { samples were collected, in feet, and is }
\end{array}
$$

$$
\begin{aligned}
& \text { equal to the increment width times the total } \\
& \text { number of vertical samples; } \\
& t_{T} \quad \text { is the total time the sampler was on the } \\
& \text { streambed, in seconds, computed by } \\
& \text { multiplying the individual sample time by } \\
& \text { the total number of vertical samples; and } \\
& M_{T} \quad \text { is the total mass of sample collected from all } \\
& \text { verticals sampled in the cross section, in } \\
& \text { grams. }
\end{aligned}
$$

\section{Estimated Sediment Load}

The second method to estimate sediment transport utilized a model to overcome the challenge of quantifying bedload. Einstein (1950) presented a technique for computing the transport of sediment with grain sizes present in appreciable quantities in the streambed, or the bed-material load. This method was a probabilistic relation of SSC with stream-velocity over a given vertical profile, and for a finite longitudinal distance along a given river reach. Later, Colby and Hembree (1955) and Colby and Hubbell (1967) developed a modified version of Einstein's procedure (MEP) that used sediment and hydraulic data from a single cross section to calculate the total bed-material load for a specific stream reach. The MEP is considered an improvement over the original Einstein method because it is simpler in computation and it uses characteristics more readily available from typical measurements of sediment. The MEP model was implemented using the executable program Bureau of Reclamation Automated Modified Einstein Procedure (BORAMEP) (U.S. Bureau of Reclamation, 2010). Input data needed for the MEP model include streamflow, average channel velocity, wetted channel width, average channel depth, water-surface slope, water temperature, SSC, the grain-size distributions of the suspended sediment and bed material, and the proportion of the suspended sediment also represented in the bed. Water-surface slope was assumed to be the slope of the streambed; however, sensitivity analysis indicated that slope did not affect results even when varied over three orders of magnitude relative to the streambed slope.

Although MEP estimates are commonly referred to as "total-sediment discharge" procedures (Einstein, 1950; Colby and Hembree, 1955), it is important to note that the predictive capacity of the MEP is limited to estimates of the bed-material load, or the sediment transport of grain sizes represented in the streambed. The transport of wash load is derived from erosional processes external to the local river reach such as rainfall-derived runoff, tributary inputs, and bank erosion. Therefore, it is a supply-dependent component of sediment transport, and must be incorporated separately. However, the measurements of suspended-sediment load include the wash load and portions of the bed-material load. For this report, the wash load was classified as the portion of the suspendedsediment load consisting of grain sizes finer than that represented in the bed (table 2). More specifically, the fifthpercentile diameter of the bed-material grain-size distribution was used as the threshold for classifying the suspended-load 
components. Grain sizes finer than the threshold diameter were considered wash load and grain sizes coarser than the threshold diameter were considered bed-material load that was in suspension. Because the MEP method utilizes the suspended bed-material load to predict the total bed-material load, the wash load was removed from the suspended-sediment load before input to the BORAMEP program. The wash load was then added back to the BORAMEP-derived estimate of bed-material load to produce the MEP estimated total-sediment load (Colby and Hembree, 1955).

\section{Sediment Characteristics in the Missouri River}

The sediment characteristics of the Missouri River during the high-flow conditions in 2011 are described in terms of the transport of sediment in suspension and bedload. Suspendedsediment concentration and grain-size distribution, bedload mass and grain-size distribution, and grain-size distribution of the bed material were measured throughout the high-flow event at six sites on the Missouri. The sediment data, along with streamflow information, were used to describe the sediment loads that moved past the sites during the high-flow conditions.

\section{Suspended-Sediment Characteristics}

The pattern of streamflow during the 2011 flood was different between the middle and lower segments of the Missouri River, and these patterns, as well as differences in number of samples, channel geomorphology, and tributary sediment supplies, resulted in differences in characteristics of sediment transport between sites. In the middle segment (sites 1 and 2), streamflow increased and peaked in late June, held roughly steady through early July, then gradually receded, with intermittent increases or decreases, until later September, after which flows held steady (fig. 2). Although the flow pattern of the 2011 flood varied slightly between sites in the lower segment (sites 3-6), the general flow pattern was the same: a relatively rapid increase in discharge from early June to late June, steady high flows from late June to late August, a gradual decline from late August to early October, and steady flows thereafter (fig. 2).

A wider range in SSC was observed in the middle segment of the Missouri River compared to sites in the lower segment (fig. 3). More samples were collected at a wider range of streamflows at the sites in the middle segment compared to sites in the lower segment, and these included samples as flows were increasing, which often have the highest concentrations. Median SSCs in the middle segment of the Missouri River were $194 \mathrm{mg} / \mathrm{L}$ at site 1 and $338 \mathrm{mg} / \mathrm{L}$ at site 2 (fig. 3 and table 3). In the lower segment of the Missouri River, median $\mathrm{SSC}$ ranged from $236 \mathrm{mg} / \mathrm{L}$ at site 6 to $373 \mathrm{mg} / \mathrm{L}$ at site 4 .

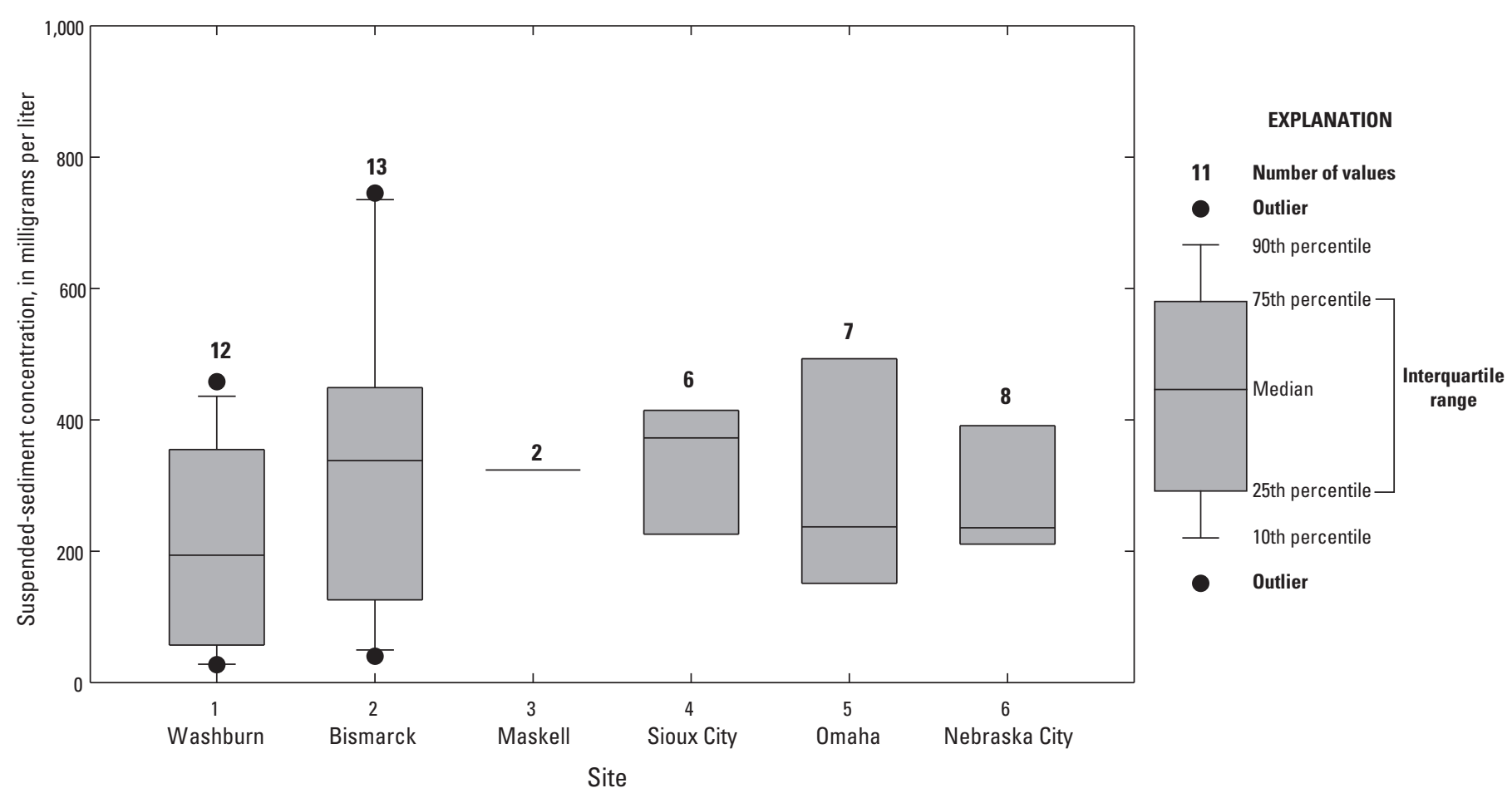

Figure 3. Distribution of suspended-sediment concentrations at six sites on the Missouri River during the 2011 high-flow conditions. 
Table 3. Streamflow, suspended-sediment concentrations, and grain size for six sites on the Missouri River during the 2011 high-flow conditions.

[ $\mathrm{ft}^{3} / \mathrm{s}$, cubic feet per second; $\mathrm{mg} / \mathrm{L}$, milligram per liter; $\mathrm{mm}$, millimeter; +, rising stage; -, falling stage]

\begin{tabular}{|c|c|c|c|c|c|c|c|c|c|}
\hline \multirow[b]{2}{*}{ Date } & \multirow[b]{2}{*}{$\begin{array}{c}\text { Stage } \\
\text { condition }\end{array}$} & \multirow{2}{*}{$\begin{array}{c}\text { Daily mean } \\
\text { stream flow } \\
\left(\mathrm{ft}^{3} / \mathrm{s}\right)\end{array}$} & \multirow{2}{*}{$\begin{array}{l}\text { Suspended- } \\
\text { sediment } \\
\text { concentration } \\
\text { (mg/L) }\end{array}$} & \multicolumn{6}{|c|}{ Suspended-sediment fall diameter (grain size) (percent in size range) } \\
\hline & & & & $\begin{array}{c}\text { Less than } \\
0.062 \\
\text { mm }\end{array}$ & $\begin{array}{c}0.062 \text { to } 0.125 \\
\mathrm{~mm}\end{array}$ & $\begin{array}{c}0.125 \text { to } 0.250 \\
\mathrm{~mm}\end{array}$ & $\begin{array}{c}0.250 \text { to } 0.500 \\
\mathrm{~mm}\end{array}$ & $\begin{array}{c}0.500 \text { to } 1 \\
\mathrm{~mm}\end{array}$ & $\begin{array}{c}1 \text { to } 2 \\
\mathrm{~mm}\end{array}$ \\
\hline \multicolumn{10}{|c|}{ Missouri River at Washburn, North Dakota (site 1) } \\
\hline $06 / 16 / 2011$ & + & 147,000 & 458 & 31 & 4 & 27 & 38 & 0 & 0 \\
\hline $06 / 22 / 2011$ & + & 151,000 & 384 & 21 & 16 & 55 & 8 & 0 & 0 \\
\hline 07/06/2011 & - & 143,000 & 297 & 16 & 21 & 59 & 4 & 0 & 0 \\
\hline $07 / 14 / 2011$ & - & 131,000 & 221 & 17 & 19 & 62 & 2 & 0 & 0 \\
\hline $07 / 27 / 2011$ & - & 114,000 & 374 & 9 & 26 & 46 & 10 & 9 & 0 \\
\hline 08/04/2011 & - & 108,000 & 167 & 13 & 13 & 68 & 3 & 3 & 0 \\
\hline $09 / 22 / 2011$ & - & 30,800 & 30 & 53 & 19 & 28 & 0 & 0 & 0 \\
\hline 09/29/2011 & - & 24,300 & 27 & 75 & 11 & 8 & 6 & 0 & 0 \\
\hline Mean & & 98,767 & 203 & 28 & 17 & 45 & 10 & 1 & 0 \\
\hline Median & & 111,000 & 194 & 21 & 16 & 49 & 8 & $\mathbf{0}$ & $\mathbf{0}$ \\
\hline \multicolumn{10}{|c|}{ Missouri River at Bismarck, North Dakota (site 2) } \\
\hline 06/09/2011 & + & 138,000 & 745 & 38 & 10 & 35 & 17 & 0 & 0 \\
\hline $06 / 15 / 2011$ & + & 142,000 & 721 & 18 & 9 & 43 & 28 & 2 & 0 \\
\hline $06 / 23 / 2011$ & + & 151,000 & 480 & 22 & 20 & 39 & 19 & 0 & 0 \\
\hline 07/01/2011 & - & 146,000 & 418 & 14 & 24 & 39 & 23 & 0 & 0 \\
\hline $09 / 15 / 2011$ & - & 51,000 & 109 & 25 & 24 & 47 & 4 & 0 & 0 \\
\hline $09 / 22 / 2011$ & - & 34,500 & 64 & 48 & 18 & 34 & 0 & 0 & 0 \\
\hline $09 / 29 / 2011$ & - & 28,200 & 40 & 61 & 16 & 11 & 12 & 0 & 0 \\
\hline Mean & & 104,115 & 334 & 24 & 16 & 42 & 14 & 4 & 0 \\
\hline Median & & 120,000 & 338 & 20 & 18 & 43 & 15 & 0 & 0 \\
\hline \multicolumn{10}{|c|}{ Missouri River near Maskell, Nebraska (site 3) } \\
\hline $06 / 23 / 2011$ & - & 156,000 & ${ }^{1} 830$ & ${ }^{1} 11$ & ${ }^{1} 4$ & 130 & ${ }^{1} 55$ & ${ }^{1} 0$ & ${ }^{1} 0$ \\
\hline $06 / 30 / 2011$ & - & 168,000 & 261 & 29 & 14 & 48 & 9 & 0 & 0 \\
\hline $07 / 21 / 2011$ & - & 179,000 & 1760 & 19 & ${ }^{13}$ & 132 & ${ }^{1} 48$ & ${ }^{18}$ & ${ }^{1} 0$ \\
\hline 08/04/2011 & - & 161,000 & 386 & 17 & 6 & 42 & 33 & 2 & 0 \\
\hline $08 / 18 / 2011$ & - & 154,000 & 1895 & 17 & 13 & 128 & ${ }^{1} 58$ & 14 & ${ }^{1} 0$ \\
\hline $09 / 01 / 2011$ & - & 99,000 & 1822 & 17 & 13 & ${ }^{1} 19$ & ${ }^{1} 69$ & ${ }^{12}$ & ${ }^{1} 0$ \\
\hline $09 / 15 / 2011$ & - & 93,500 & 13,250 & 12 & ${ }^{1} 0$ & 126 & ${ }^{1} 53$ & ${ }^{1} 17$ & 12 \\
\hline
\end{tabular}




\section{Sediment Transport at Selected Sites along the Missouri River during the High-Flow Conditions of 2011}

Table 3. Streamflow, suspended-sediment concentrations, and grain size for six sites on the Missouri River during the 2011 high-flow conditions.-Continued

[ $\mathrm{ft}^{3} / \mathrm{s}$, cubic feet per second; mg/L, milligram per liter; mm, millimeter; +, rising stage; -, falling stage]

\begin{tabular}{|c|c|c|c|c|c|c|c|c|c|}
\hline \multirow[b]{2}{*}{ Date } & \multirow[b]{2}{*}{$\begin{array}{c}\text { Stage } \\
\text { condition }\end{array}$} & \multirow[b]{2}{*}{$\begin{array}{c}\text { Daily mean } \\
\text { stream flow } \\
\left(\mathrm{ft}^{3} / \mathbf{s}\right)\end{array}$} & \multirow{2}{*}{$\begin{array}{l}\text { Suspended- } \\
\text { sediment } \\
\text { concentration } \\
\text { (mg/L) }\end{array}$} & \multicolumn{6}{|c|}{ Suspended-sediment fall diameter (grain size) (percent in size range) } \\
\hline & & & & $\begin{array}{c}\text { Less than } \\
0.062 \\
\text { mm }\end{array}$ & $\begin{array}{c}0.062 \text { to } 0.125 \\
\mathrm{~mm}\end{array}$ & $\begin{array}{c}0.125 \text { to } 0.250 \\
\mathrm{~mm}\end{array}$ & $\begin{array}{c}0.250 \text { to } 0.500 \\
\mathrm{~mm}\end{array}$ & $\begin{array}{c}0.500 \text { to } 1 \\
\mathrm{~mm}\end{array}$ & $\begin{array}{c}1 \text { to } 2 \\
\mathrm{~mm}\end{array}$ \\
\hline \multicolumn{10}{|c|}{ Missouri River near Maskell, Nebraska (site 3)—Continued } \\
\hline $11 / 02 / 2011$ & - & 43,800 & 12,270 & 12 & ${ }^{1} 0$ & 19 & ${ }^{173}$ & ${ }^{1} 16$ & ${ }^{1} 0$ \\
\hline Mean & & 109,667 & 216 & 15 & 7 & 30 & 14 & 1 & $\mathbf{0}$ \\
\hline Median & & 164,500 & 324 & 23 & 10 & 45 & 21 & 1 & $\mathbf{0}$ \\
\hline \multicolumn{10}{|c|}{ Missouri River at Sioux City, lowa (site 4) } \\
\hline 07/01/2011 & - & 179,000 & 449 & 22 & 3 & 28 & 22 & 5 & 11 \\
\hline 08/05/2011 & - & 164,000 & 367 & 23 & 7 & 42 & 26 & 2 & 0 \\
\hline 08/19/2011 & - & 160,000 & 378 & 23 & 8 & 39 & 27 & 3 & 0 \\
\hline 09/02/2011 & - & 101,000 & 201 & 34 & 8 & 32 & 23 & 3 & 0 \\
\hline 09/16/2011 & - & 94,300 & 234 & 27 & 12 & 38 & 20 & 3 & 0 \\
\hline $11 / 01 / 2011$ & - & 42,500 & 403 & 14 & 9 & 44 & 33 & 0 & 0 \\
\hline Mean & & 123,467 & 339 & 24 & 8 & 37 & 25 & 3 & 2 \\
\hline Median & & 130,500 & 373 & 23 & 8 & 39 & 25 & 3 & $\mathbf{0}$ \\
\hline \multicolumn{10}{|c|}{ Missouri River at Omaha, Nebraska (site 5) } \\
\hline 07/08/2011 & - & 190,000 & 778 & 19 & 3 & 32 & 42 & 3 & 1 \\
\hline 07/18/2011 & + & 191,000 & 356 & 40 & 5 & 27 & 23 & 5 & 0 \\
\hline 08/01/2011 & - & 186,000 & 237 & 44 & 4 & 24 & 26 & 2 & 0 \\
\hline 08/15/2011 & - & 168,000 & 493 & 18 & 1 & 21 & 57 & 3 & 0 \\
\hline 08/29/2011 & - & 132,000 & 207 & 44 & 5 & 21 & 27 & 3 & 0 \\
\hline 09/12/2011 & - & 102,000 & 150 & 54 & 9 & 18 & 19 & 0 & 0 \\
\hline $10 / 31 / 2011$ & + & 47,300 & 151 & 43 & 13 & 25 & 19 & 0 & 0 \\
\hline Mean & & 145,186 & 339 & 37 & 6 & 24 & 30 & 2 & $\mathbf{0}$ \\
\hline Median & & 168,000 & 237 & 43 & 5 & 24 & 26 & 3 & $\mathbf{0}$ \\
\hline \multicolumn{10}{|c|}{ Missouri River at Nebraska City, Nebraska (site 6) } \\
\hline 06/21/2011 & + & ${ }^{2} 195,000$ & 427 & 79 & 5 & 4 & 12 & 0 & 0 \\
\hline 06/27/2011 & + & ${ }^{2} 193,000$ & 494 & 75 & 2 & 14 & 7 & 2 & 0 \\
\hline 07/19/2011 & - & ${ }^{2} 141,000$ & 207 & 82 & 4 & 13 & 1 & 0 & 0 \\
\hline 08/02/2011 & - & ${ }^{2} 144,000$ & 283 & 54 & 5 & 14 & 19 & 8 & 0 \\
\hline 08/16/2011 & - & ${ }^{2} 136,000$ & 248 & 41 & 7 & 25 & 23 & 4 & 0 \\
\hline 08/30/2011 & - & ${ }^{2} 110,000$ & 206 & 53 & 6 & 30 & 11 & 0 & 0 \\
\hline 09/13/2011 & - & ${ }^{2} 93,300$ & 222 & 53 & 8 & 23 & 12 & 4 & 0 \\
\hline $11 / 03 / 2011$ & - & 54,200 & 223 & 42 & 4 & 30 & 20 & 4 & 0 \\
\hline Mean & & 133,313 & 289 & 60 & 5 & 19 & 13 & 3 & 0 \\
\hline Median & & 138,500 & 236 & 54 & 5 & 19 & 12 & 3 & 0 \\
\hline
\end{tabular}

${ }^{1}$ Value is considered erroneous as the presumed result of the sample being compromised by bed material particles.

${ }^{2}$ Streamflow adjusted to include only the portion of streamflow in the main channel. 
SSCs ranged from 27 to $458 \mathrm{mg} / \mathrm{L}$ at site 1 and from 40 to $745 \mathrm{mg} / \mathrm{L}$ at site 2 (table 3). In the lower segment of the Missouri River, SSCs ranged from 261 to $386 \mathrm{mg} / \mathrm{L}$ at site 3, from 201 to $449 \mathrm{mg} / \mathrm{L}$ at site 4 , from 150 to $778 \mathrm{mg} / \mathrm{L}$ at site 5 , and from 206 to $494 \mathrm{mg} / \mathrm{L}$ at site 6 (table 3).

Although seven suspended-sediment samples were collected from site 3, SSC and suspended-sediment-load (described in the Total Sediment Load section) comparisons to the other sites suggested that five of those seven samples became compromised with bed material, which can occur if the sampler nozzle comes in contact with the streambed. Attempts were made to salvage the five samples, but ultimately it was decided to not include suspended-sediment data from those samples in the interpretive discussion in this report. Although the samples were considered compromised with bed material, SSC results from these samples are presented in table 3.

SSC varied with time during the high-flow conditions at the six sites on the Missouri River in 2011, and signatures of fine-sediment (grain sizes less than 0.062 millimeters [mm]) supply depletions were apparent at sites 1, 2, 3, and 5 (fig. 4). In the middle segment of the Missouri River, SSC increased and peaked as flows increased and started to plateau, but while flows were still high and steady, SSC decreased and suspended-sediment grain sizes coarsened (fig. 4), indicating the decrease was possibly related to fine-sediment supply limitations (Topping and others, 2000). Three samples collected in July and August at sites 1 and 2 indicated subtle increases in SSC as well as a coarser distribution of grain sizes than most of the other samples (fig. 4, table 3). The change in suspended-sediment characteristics for these three samples may be the result of channel bank or bed erosional processes in the Missouri River channel because a coincident increase in streamflow from the upstream tributary (Knife River) was not observed.

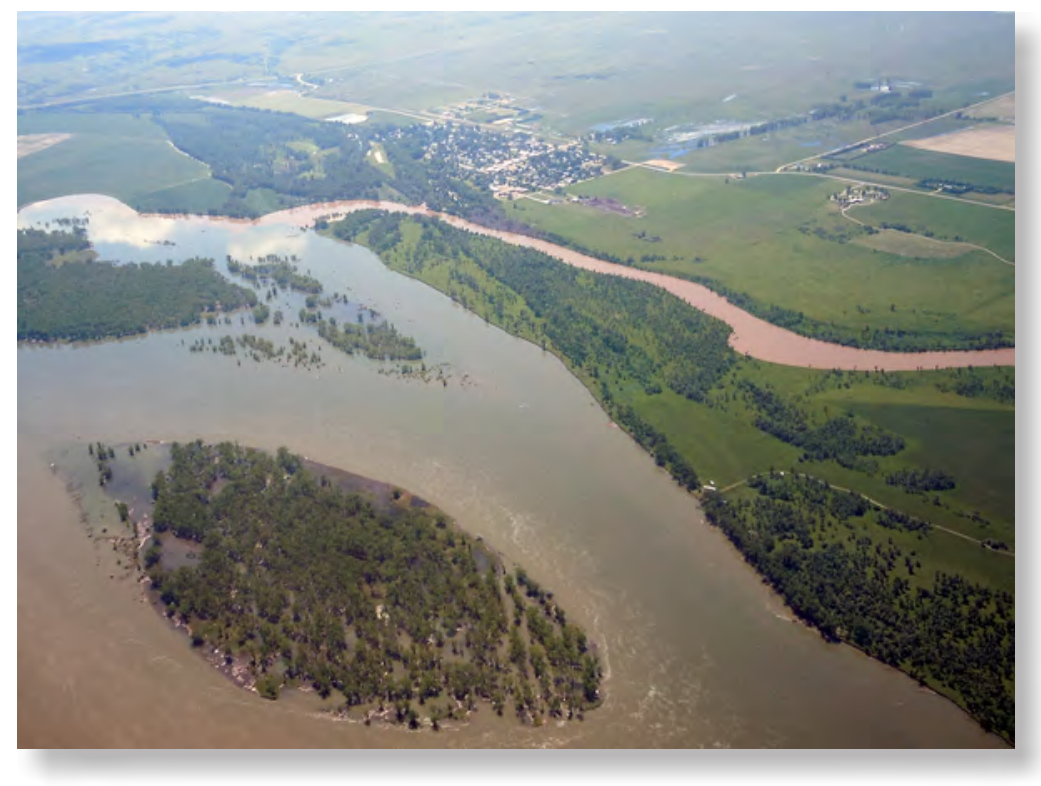

Confluence of the Knife River and the Missouri River, June 23, 2011 (photograph by Joel M. Galloway, U.S. Geological Survey).
The temporal pattern of SSC in the lower Missouri River varied by location (fig. 4). Too few quality measurements were made at site 3 to define any pattern in SSC. At site 4, SSC generally was steady while high flows were steady, decreased in September when flow decreased and then increased in the sample in November. The increase in SSC in November may have been attributed to episodic flood-recession processes such as streambank failures, because no substantial rainfall-runoff event occurred in the area at that time. Samples collected as part of another project at site 4 also indicated SSCs fluctuating from 230 to $517 \mathrm{mg} / \mathrm{L}$ in 10 samples collected from October 14 to November 15 during approximately steady streamflow conditions (http://nwis.waterdata.usgs.gov/ne/nwis/qwdata). At sites 5 and 6, SSC was highest early in the high-flow event, but decreased substantially even as streamflows generally were steady or slightly decreasing, and then SSC slightly decreased as streamflow decreased through November. At sites 5 and 6, the substantial decrease in SSC over generally constant peak streamflows and gradual increase in relative proportion of sand-sized particles (greater than $0.062 \mathrm{~mm}$ in diameter) in the suspended sediment indicated that fine-sediment supplies were being depleted over the high-flow event; however, the generally steady SSC during the decrease in streamflow indicated that additional sources of sediment likely became available as streamflow was receding. Analysis of tributary streamflows at all of the lower-segment sites did not explain the intermittent increases in SSC that occurred during August at sites 5 and 6.

With the exception of sites 5 and 6 , suspended sediment mainly was composed of grain sizes ranging from 0.125 to $0.500 \mathrm{~mm}$ in most samples (fig. 4, table 3 ). At site 5 , suspended sediment was dominated by grain sizes between 0.250 to $0.500 \mathrm{~mm}$ (fig. 4, table 3). At site 6 , suspended sediment was generally dominated by grain sizes finer than $0.062 \mathrm{~mm}$. The relatively coarse grains in suspension at site 5 likely are the result of the confined flood flows and consequent increase in hydraulic energy through the reach, which may have caused a substantial increase in the proportion of bed material in suspension. The greater dominance of finer sediments (diameters less than $0.062 \mathrm{~mm}$ ) in suspension at site 6 likely was the result of fine-sediment contributions from the Platte River, which had consistently high and steady base flows throughout 2011.

Changes in suspended-sediment grain size varied among the four sites in the lower segment of the Missouri River throughout the event (fig. 4 and table 3). At site 3, most of the samples were predominately composed of material ranging in grain size from 0.125 to $0.500 \mathrm{~mm}$ (from only 2 samples). At sites 4 and 5, coarser-grained material dominated the suspended sediment in the first sample compared to subsequent samples. At site 4 , the suspended sediment was composed of some material with grain sizes in the 0.500 to $2 \mathrm{~mm}$ range in the first sample collected on July 1, whereas subsequent samples were dominated by grain sizes less than $0.062 \mathrm{~mm}$ 


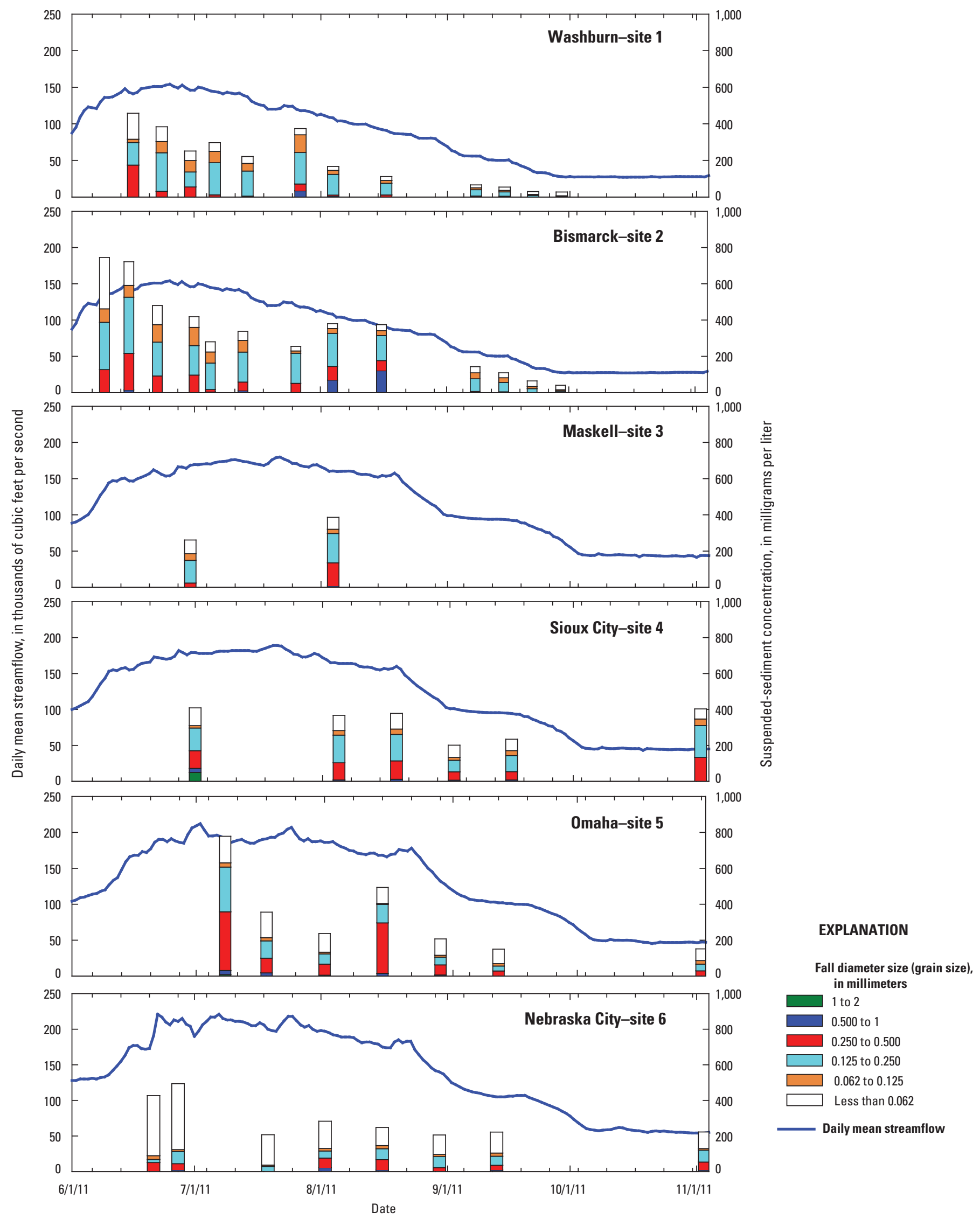

Figure 4. Time series of suspended-sediment concentration, grain-size distribution, and daily mean streamflow for six sites on the Missouri River during the 2011 high-flow conditions. 
and from 0.125 to $0.500 \mathrm{~mm}$ (fig. 4). At site 5 , the grainsize distribution was similar to site 4 , with most of the first sample (collected July 8) composed of material in the 0.125 to $0.500 \mathrm{~mm}$ range, and subsequent samples dominated by material less than $0.062 \mathrm{~mm}$ and from 0.125 to $500 \mathrm{~mm}$ (fig. 4). The distribution in grain sizes in the suspended sediment collected at site 6 was dominated by finer material less than 0.062 $\mathrm{mm}$ throughout the high-flow event. Several samples collected on the rise and early fall of the streamflow hydrograph had a larger portion of suspended material in the 0.250 to $0.500 \mathrm{~mm}$ range (fig. 4 and table 3).

\section{Bedload Transport Characteristics}

Measured bedload transport rates in the lower segment of the Missouri River (sites 3 to 6), where sand supplies from the banks and bed of the unchannelized reach and tributaries would be expected to be greater, were consistently higher than those in the middle segment (sites 1 and 2) during the high-flow conditions in 2011 (fig. 5 and table 4). The median measured bedload transport rate at site 1 was 517 tons per day (tons/d) and ranged from 164 to 2,890 tons/d. The median bedload transport rate at site 2 was 1,500 tons/d and ranged from 142 to 8,890 tons/d. Measured bedload transport rates were highest at site 3 then decreased downstream to site 5 , then increased at site 6 . The median measured bedload transport rate for site 3 was 22,100 tons/d and ranged from 6,260 to 32,900 tons/d. Median measured bedload transport rates at sites downstream from site 3 were 5,640 tons/d at site 4 ; 3,930 tons/d at site 5; and 8,450 tons/d at site 6 .

There are several possible explanations for the distinct pattern of decreasing measured bedload transport rates from sites 3 to 5 . The decrease in measured bedload transport from site 3 to 5 may have been a result of progressively increasing channel constriction from site 3 (unchannelized reach) to site 5 (completely channelized reach) and deposition of bedloadsized particles between stations. The increase in bedload transport rates at Nebraska City, Nebr. most likely was the result of increased sediment supply from the Platte River.

Measured bedload transport varied with time during the high-flow conditions at the six sites on the Missouri River in 2011 (fig. 6 and table 4). At the two sites in the middle segment of the Missouri River, the greatest bedload was measured during the recession of the streamflow hydrograph. During the rise, peak, and early fall of the streamflow hydrograph (June 16 through July 14), the bedload measured at site 1 ranged from 164 to 625 tons/d. In the subsequent samples collected July 27 through August 17, the bedload ranged from 2,790 tons/d to 2,890 tons/d. Likewise, at site 2, the bedload ranged from 1,340 to 2,540 tons/d on the rise, peak, and early fall of the streamflow hydrograph, and in the subsequent samples collected July 26 and August 4, the measured bedloads were 8,530 and 8,890 tons/d, respectively. A similar pattern was observed at sites $3-5$ in the lower segment of the Missouri River, where the greatest bedload was measured later in the event on the fall of the streamflow hydrograph, although the change in bedload was not as dramatic as observed at the

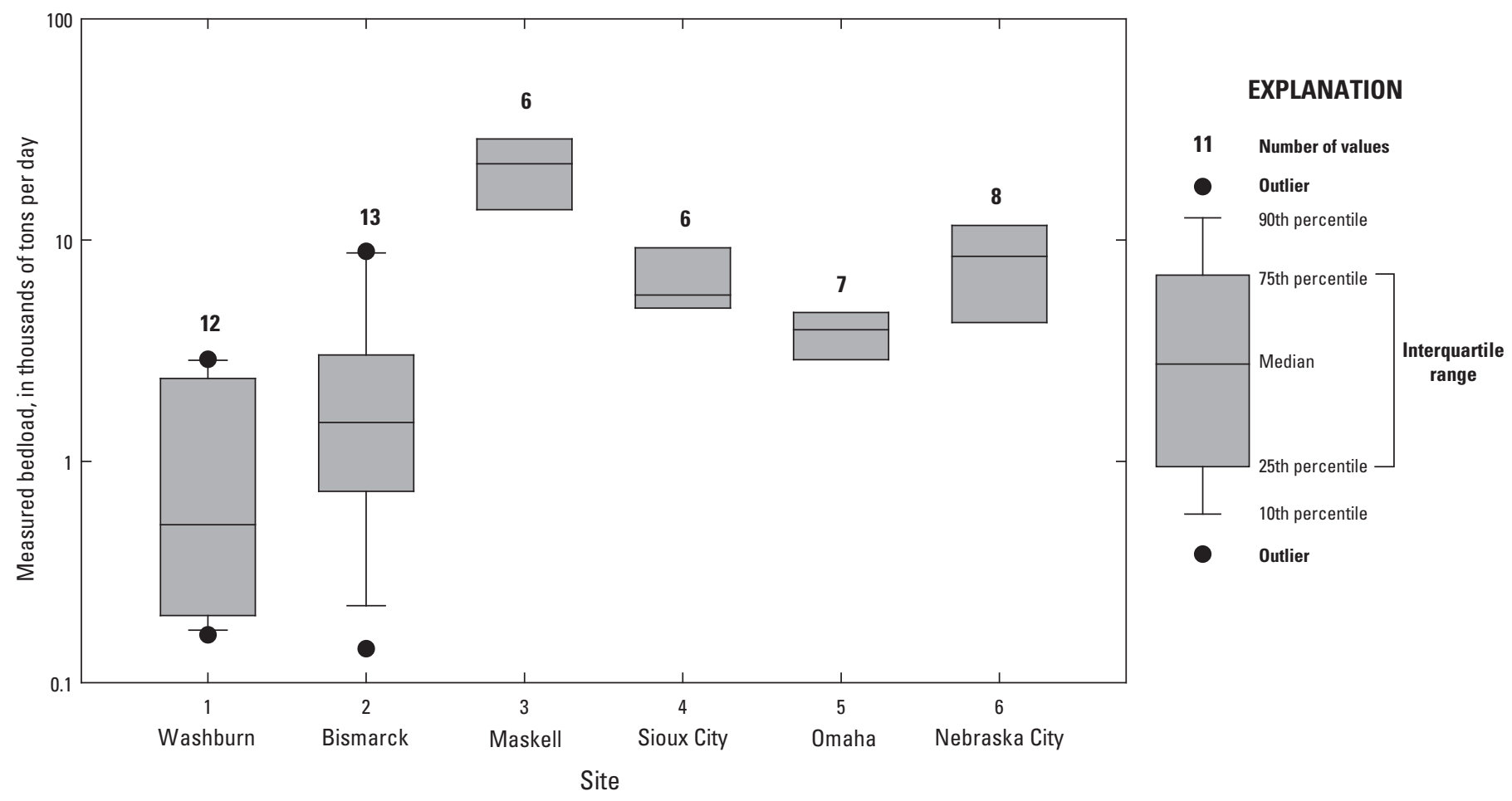

Figure 5. Distribution of bedload at six sites on the Missouri River during the 2011 high-flow conditions. 
Table 4. Grain sizes and mass of bedload samples for six sites on the Missouri River during the 2011 high-flow conditions.

$[\mathrm{mm}$, millimeter; tons/d, tons per day]

\begin{tabular}{|c|c|c|c|c|c|c|c|c|c|c|}
\hline \multirow[b]{2}{*}{ Date } & \multicolumn{9}{|c|}{ Bedload-sediment fall diameter (grain size) (percent in size range) } & \multirow{2}{*}{$\begin{array}{r}\text { Measured } \\
\text { bedload } \\
\text { (tons/d) }\end{array}$} \\
\hline & $\begin{array}{c}0.062 \text { to } 0.125 \\
\mathrm{~mm}\end{array}$ & $\begin{array}{c}0.125 \text { to } 0.250 \\
\mathrm{~mm}\end{array}$ & $\begin{array}{c}0.250 \text { to } 0.500 \\
\mathrm{~mm}\end{array}$ & $\begin{array}{c}0.500 \text { to } 1 \\
\mathrm{~mm}\end{array}$ & $\begin{array}{c}1 \text { to } 2 \\
\mathrm{~mm}\end{array}$ & $\begin{array}{c}2 \text { to } 4 \\
\mathrm{~mm}\end{array}$ & $\begin{array}{c}4 \text { to } 8 \\
\mathrm{~mm}\end{array}$ & $\begin{array}{c}8 \text { to } 16 \\
\mathrm{~mm}\end{array}$ & $\begin{array}{c}16 \text { to } 32 \\
\mathrm{~mm}\end{array}$ & \\
\hline \multicolumn{11}{|c|}{ Missouri River at Washburn, North Dakota (site 1) } \\
\hline $06 / 16 / 2011$ & 4 & 51 & 34 & 4 & 1 & 1 & 1 & 4 & 0 & 344 \\
\hline $06 / 23 / 2011$ & 3 & 41 & 45 & 3 & 0 & 1 & 1 & 3 & 3 & 625 \\
\hline $06 / 30 / 2011$ & 4 & 54 & 34 & 2 & 0 & 1 & 3 & 1 & 0 & 206 \\
\hline 07/06/2011 & 2 & 55 & 35 & 4 & 1 & 0 & 0 & 3 & 0 & 164 \\
\hline $07 / 14 / 2011$ & 5 & 72 & 19 & 2 & 2 & 0 & 0 & 0 & 0 & 479 \\
\hline $07 / 27 / 2011$ & 0 & 24 & 72 & 2 & 1 & 0 & 1 & 0 & 0 & 2,790 \\
\hline 08/04/2011 & 0 & 11 & 68 & 8 & 2 & 1 & 2 & 4 & 4 & 2,890 \\
\hline 08/17/2011 & 0 & 13 & 79 & 4 & 2 & 1 & 1 & 0 & 0 & 2,790 \\
\hline 09/08/2011 & 0 & 7 & 73 & 4 & 3 & 4 & 5 & 4 & 0 & 1,100 \\
\hline $09 / 15 / 2011$ & 0 & 1 & 56 & 24 & 4 & 5 & 9 & 1 & 0 & 192 \\
\hline $09 / 22 / 2011$ & 0 & 4 & 81 & 13 & 2 & 0 & 0 & 0 & 0 & 199 \\
\hline 09/29/2011 & 0 & 3 & 70 & 21 & 2 & 3 & 1 & 0 & 0 & 554 \\
\hline Mean & 2 & 28 & 56 & 8 & 2 & 1 & 2 & 2 & 1 & 1,028 \\
\hline Median & $\mathbf{0}$ & 19 & 62 & 4 & 2 & 1 & 1 & 1 & $\mathbf{0}$ & 517 \\
\hline \multicolumn{11}{|c|}{ Missouri River at Bismarck, North Dakota (site 2) } \\
\hline 06/09/2011 & 3 & 46 & 45 & 4 & 1 & 0 & 1 & 0 & 0 & 1,500 \\
\hline $06 / 15 / 2011$ & 2 & 43 & 51 & 3 & 0 & 1 & 0 & 0 & 0 & 1,270 \\
\hline $06 / 22 / 2011$ & 1 & 21 & 57 & 14 & 4 & 1 & 2 & 0 & 0 & 2,160 \\
\hline 07/01/2011 & 1 & 21 & 39 & 33 & 3 & 1 & 1 & 1 & 0 & 2,470 \\
\hline $07 / 05 / 2011$ & 2 & 19 & 40 & 30 & 4 & 0 & 2 & 0 & 3 & 1,340 \\
\hline $07 / 13 / 2011$ & 1 & 20 & 36 & 34 & 6 & 2 & 1 & 0 & 0 & 2,540 \\
\hline $07 / 26 / 2011$ & 0 & 13 & 47 & 27 & 7 & 2 & 2 & 2 & 0 & 8,530 \\
\hline 08/04/2011 & 1 & 17 & 49 & 19 & 5 & 2 & 1 & 0 & 6 & 8,890 \\
\hline 08/16/2011 & 0 & 7 & 48 & 26 & 8 & 5 & 4 & 2 & 0 & 3,510 \\
\hline 09/08/2011 & 0 & 3 & 44 & 29 & 8 & 5 & 4 & 7 & 0 & 871 \\
\hline $09 / 15 / 2011$ & 0 & 5 & 68 & 18 & 5 & 2 & 2 & 0 & 0 & 594 \\
\hline $09 / 22 / 2011$ & 0 & 4 & 58 & 26 & 7 & 4 & 1 & 0 & 0 & 343 \\
\hline 09/29/2011 & 0 & 1 & 56 & 31 & 8 & 3 & 1 & 0 & 0 & 142 \\
\hline Mean & 1 & 17 & 49 & 23 & 5 & 2 & 2 & 1 & 1 & 2,628 \\
\hline Median & 1 & 17 & 48 & 26 & 5 & 2 & 1 & $\mathbf{0}$ & $\mathbf{0}$ & 1,500 \\
\hline \multicolumn{11}{|c|}{ Missouri River near Maskell, Nebraska (site 3) } \\
\hline $06 / 23 / 2011$ & 0 & 10 & 68 & 18 & 3 & 1 & 0 & 0 & 0 & 13,300 \\
\hline 06/30/2011 & 0 & 12 & 71 & 14 & 2 & 1 & 0 & 0 & 0 & 15,000 \\
\hline $07 / 21 / 2011$ & 0 & 8 & 65 & 23 & 2 & 1 & 1 & 0 & 0 & 29,000 \\
\hline 08/04/2011 & 0 & 15 & 59 & 20 & 3 & 1 & 1 & 1 & 0 & 32,900 \\
\hline 08/18/2011 & 0 & 13 & 63 & 18 & 4 & 1 & 1 & 0 & 0 & 27,500 \\
\hline 09/01/2011 & 0 & 7 & 59 & 27 & 4 & 2 & 1 & 0 & 0 & 16,800 \\
\hline $09 / 15 / 2011$ & 0 & 9 & 50 & 31 & 4 & 0 & 6 & 0 & 0 & 27,400 \\
\hline $11 / 02 / 2011$ & 0 & 5 & 51 & 32 & 8 & 3 & 1 & 0 & 0 & 6,260 \\
\hline Mean & $\mathbf{0}$ & 10 & 61 & 23 & 4 & 1 & 1 & $\mathbf{0}$ & $\mathbf{0}$ & 21,020 \\
\hline Median & $\mathbf{0}$ & 10 & 61 & 22 & 4 & 1 & 1 & $\mathbf{0}$ & $\mathbf{0}$ & 22,100 \\
\hline
\end{tabular}


Table 4. Grain sizes and mass of bedload samples for six sites on the Missouri River during the 2011 high-flow conditions.Continued

[mm, millimeter; tons/d, tons per day]

\begin{tabular}{|c|c|c|c|c|c|c|c|c|c|c|}
\hline \multirow[b]{2}{*}{ Date } & \multicolumn{9}{|c|}{ Bedload-sediment fall diameter (grain size) (percent in size range) } & \multirow{2}{*}{$\begin{array}{r}\text { Measurec } \\
\text { bedload } \\
\text { (tons/d) }\end{array}$} \\
\hline & $\begin{array}{c}0.062 \text { to } 0.125 \\
\mathrm{~mm}\end{array}$ & $\begin{array}{c}0.125 \text { to } 0.250 \\
\mathrm{~mm}\end{array}$ & $\begin{array}{c}0.250 \text { to } 0.500 \\
\mathrm{~mm}\end{array}$ & $\begin{array}{c}0.500 \text { to } 1 \\
\mathrm{~mm}\end{array}$ & $\begin{array}{c}1 \text { to } 2 \\
\mathrm{~mm}\end{array}$ & $\begin{array}{c}2 \text { to } 4 \\
\mathrm{~mm}\end{array}$ & $\begin{array}{c}4 \text { to } 8 \\
\mathrm{~mm}\end{array}$ & $\begin{array}{c}8 \text { to } 16 \\
\mathrm{~mm}\end{array}$ & $\begin{array}{c}16 \text { to } 32 \\
\mathrm{~mm}\end{array}$ & \\
\hline \multicolumn{11}{|c|}{ Missouri River at Sioux City, lowa (site 4) } \\
\hline 07/01/2011 & 0 & 4 & 44 & 30 & 5 & 1 & 1 & 4 & 11 & 6,070 \\
\hline 08/05/2011 & 0 & 10 & 43 & 18 & 8 & 5 & 4 & 7 & 5 & 9,450 \\
\hline 08/19/2011 & 0 & 7 & 34 & 18 & 9 & 7 & 5 & 3 & 17 & 9,140 \\
\hline 09/02/2011 & 0 & 14 & 47 & 16 & 6 & 3 & 3 & 1 & 10 & 5,100 \\
\hline 09/16/2011 & 1 & 19 & 72 & 2 & 1 & 1 & 1 & 3 & 0 & 5,210 \\
\hline $11 / 01 / 2011$ & 1 & 16 & 77 & 5 & 1 & 0 & 0 & 0 & 0 & 4,420 \\
\hline Mean & 0 & 12 & 53 & 15 & 5 & 3 & 2 & 3 & 7 & 6,565 \\
\hline Median & $\mathbf{0}$ & 12 & 46 & 17 & 6 & 2 & 2 & 3 & 8 & 5,640 \\
\hline \multicolumn{11}{|c|}{ Missouri River at Omaha, Nebraska (site 5) } \\
\hline 07/08/2011 & 0 & 3 & 65 & 27 & 4 & 1 & 0 & 0 & 0 & 3,870 \\
\hline 07/18/2011 & 0 & 3 & 49 & 27 & 11 & 1 & 1 & 0 & 8 & 2,620 \\
\hline 08/01/2011 & 0 & 5 & 62 & 27 & 5 & 0 & 1 & 0 & 0 & 3,990 \\
\hline $08 / 15 / 2011$ & 0 & 10 & 65 & 13 & 4 & 2 & 0 & 0 & 6 & 3,930 \\
\hline $08 / 29 / 2011$ & 0 & 8 & 57 & 23 & 5 & 2 & 1 & 4 & 0 & 7,020 \\
\hline 09/12/2011 & 0 & 15 & 60 & 15 & 4 & 1 & 0 & 5 & 0 & 4,710 \\
\hline $10 / 31 / 2011$ & 0 & 11 & 72 & 9 & 3 & 3 & 1 & 1 & 0 & 2,880 \\
\hline Mean & 0 & 8 & 61 & 20 & 5 & 1 & 1 & 1 & 2 & 4,146 \\
\hline Median & 0 & 8 & 62 & 23 & 4 & 1 & 1 & $\mathbf{0}$ & $\mathbf{0}$ & 3,930 \\
\hline \multicolumn{11}{|c|}{ Missouri River at Nebraska City, Nebraska (site 6) } \\
\hline $06 / 21 / 2011$ & 0 & 2 & 26 & 25 & 20 & 19 & 6 & 2 & 0 & 9,940 \\
\hline $06 / 28 / 2011$ & 0 & 1 & 23 & 40 & 22 & 10 & 3 & 1 & 0 & 16,100 \\
\hline 07/19/2011 & 0 & 3 & 27 & 37 & 18 & 7 & 3 & 5 & 0 & 12,200 \\
\hline 08/02/2011 & 0 & 4 & 32 & 35 & 17 & 9 & 2 & 1 & 0 & 9,980 \\
\hline 08/16/2011 & 0 & 5 & 22 & 32 & 19 & 12 & 7 & 3 & 0 & 6,960 \\
\hline 08/30/2011 & 0 & 19 & 33 & 24 & 15 & 8 & 1 & 0 & 0 & 6,870 \\
\hline 09/13/2011 & 0 & 12 & 48 & 21 & 12 & 4 & 2 & 1 & 0 & 3,360 \\
\hline $11 / 03 / 2011$ & 0 & 24 & 71 & 3 & 1 & 1 & 0 & 0 & 0 & 2,380 \\
\hline Mean & 0 & 9 & 35 & 27 & 16 & 9 & 3 & 2 & $\mathbf{0}$ & 8,474 \\
\hline Median & $\mathbf{0}$ & 5 & 30 & 29 & 18 & 9 & 3 & 1 & $\mathbf{0}$ & 8,450 \\
\hline
\end{tabular}



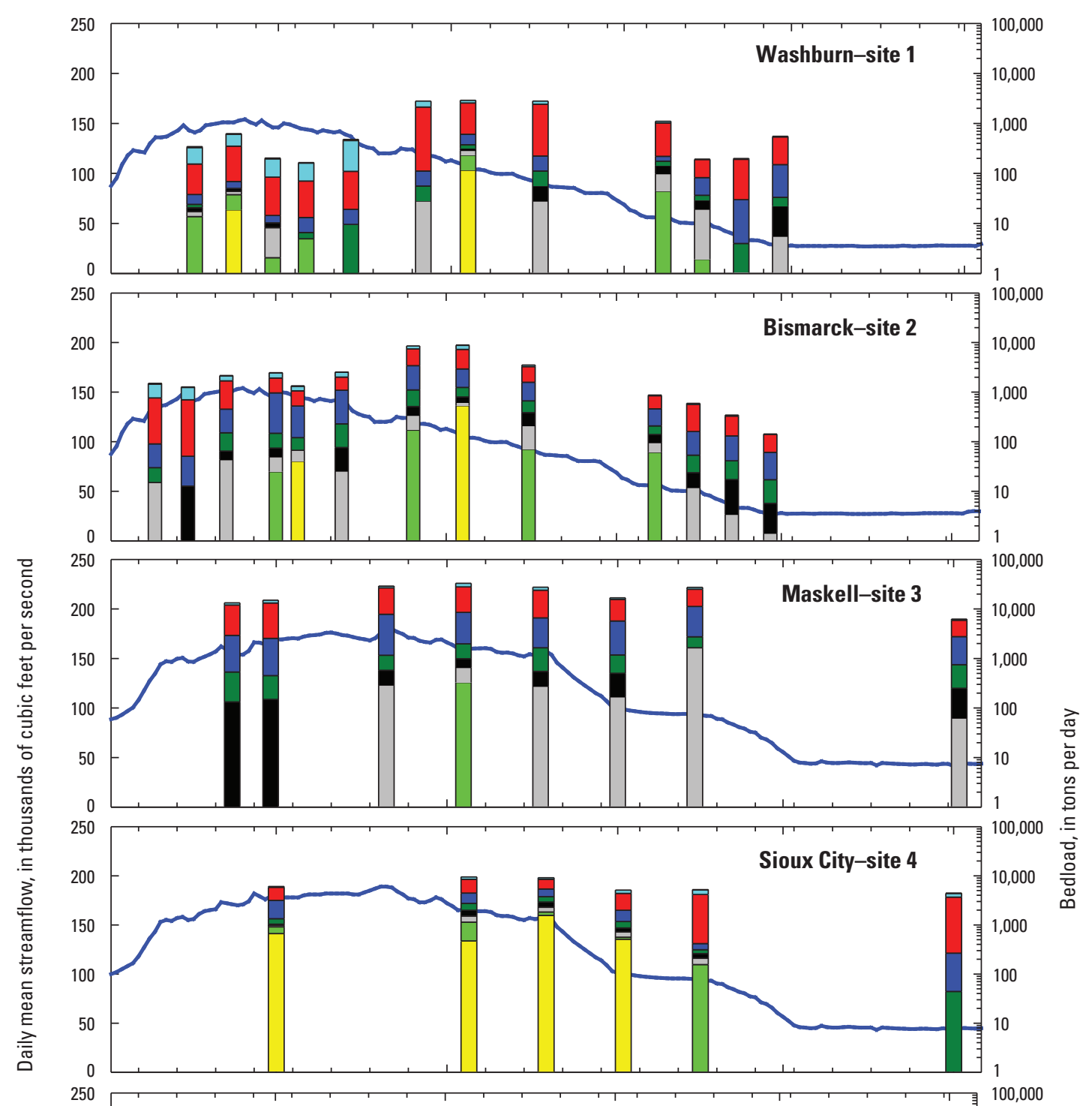

\section{EXPLANATION}

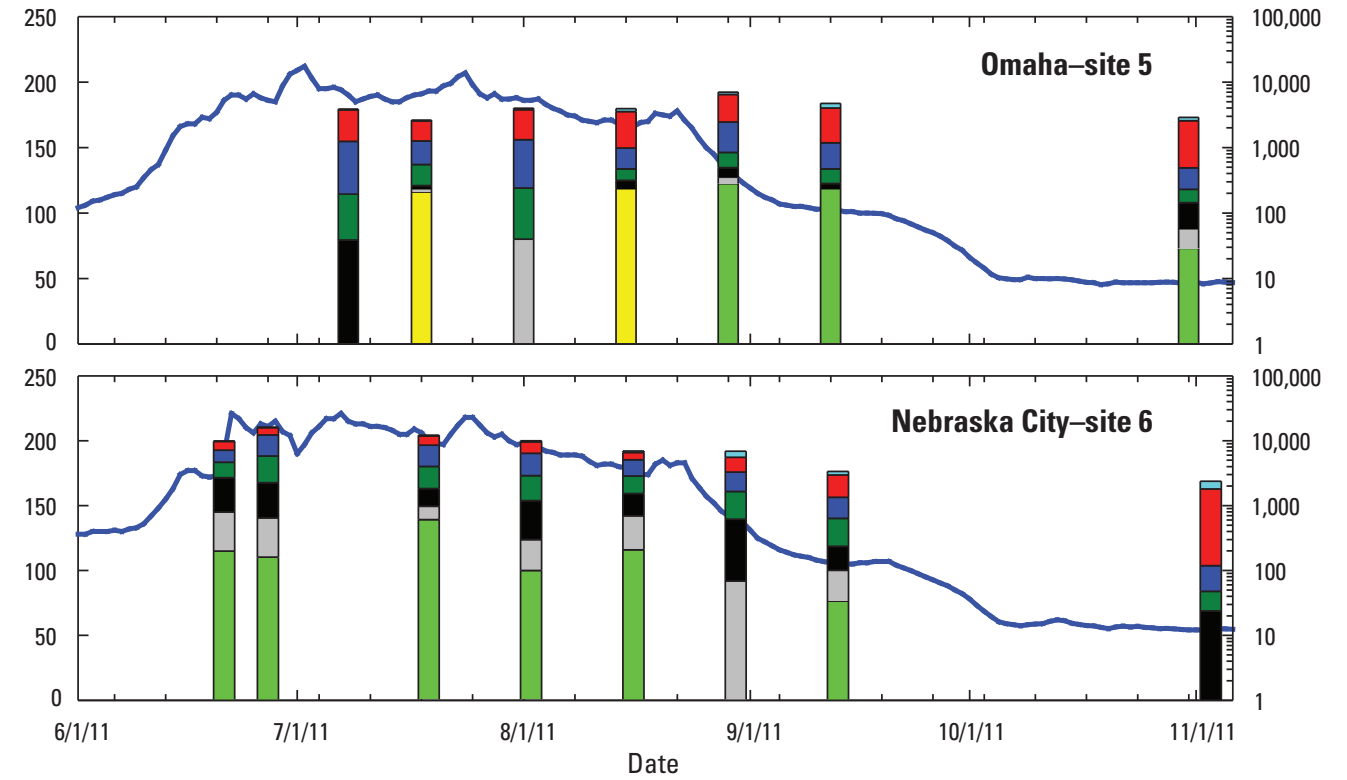

Fall diameter size (grain size), in millimeters

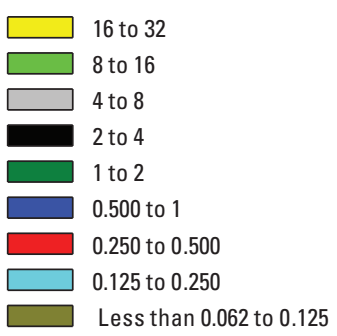

Daily mean streamflow

Figure 6. Time series of bedload, grain-size distribution, and daily mean streamflow for six sites on the Missouri River during the 2011 high-flow conditions. 
sites in middle segment of the Missouri River (fig. 6). This pattern of either varying or increasing bedload as time passed was unexpected because the streamflow tended to decrease as time passed. Presumably, the bedload should decrease as streamflow decreased. Only site 6 indicated an expected pattern where the peak bedload coincided with the peak of the streamflow hydrograph and generally decreased with decreasing streamflow throughout the event.

There are several possibilities that could explain the temporal patterns in measured bedload transport rates at sites 1 through 5 including the effectiveness of sampling during the extreme conditions, the types of bedforms in the Missouri River, and changes in the sources of sediment at the sites during the event. Measurement of bedload in a sand-bed river using trap samplers of any variety is not only difficult, but may result in large enough error as to be statistically significant (Gaeuman and Jacobson, 2007). Comparison of measured bedload transport rates to associated streamflow discharges indicates some sites have order-of-magnitude differences in measured bedload transport rates for similar discharges (fig. 7). In the absence of known bedload transport rates, or substantial quantities of quality control data, there is no way to truly address how much error is associated with the bedload measurements; however, one way to better understand the quality of the bedload data is to compare replicate samples. At sites 3-6, every bedload sample consisted of two passes across the bridge, each of which was measured separately before being composited into one sample. Although Edwards and Glysson (1999) recognize the composited result as the bedload sample (as reported in table 4), information can still be gained from a comparison of these individual passes. For each of these samples, the standard deviation of the mass from the two passes was divided by the average of the mass for the two passes to compute what is commonly referred to as the coefficient of variation (Helsel and Hirsch, 1992). Of the 29 bedload samples collected at sites 3-6, the coefficient of variation ranged between 2.1 and 49.7 percent and averaged 19.1 percent. Though this does not rule out systematic bias of the bedload data, it does suggest that the sampling technique resulted in a reasonable degree of precision.

Another possible explanation for the temporal pattern in measured bedload transport rates, in particular the increase in rates for similar or smaller streamflow, is a shift in the configuration of bedforms within the reaches. Relative to the dunesized bedforms that are typical of the Missouri River, lower bedload transport rates would be expected for either lowerregime configurations of plane-bed or ripples, or upper-regime plane-bed or anti-dune bed configurations (van Rijn, 1984; Julien, 2010). The increase in measured bedload-sediment transport rates during the slight decreases in streamflow could be associated with a transition from upper-regime to lowerregime bed configuration. Although the unusually high-flow

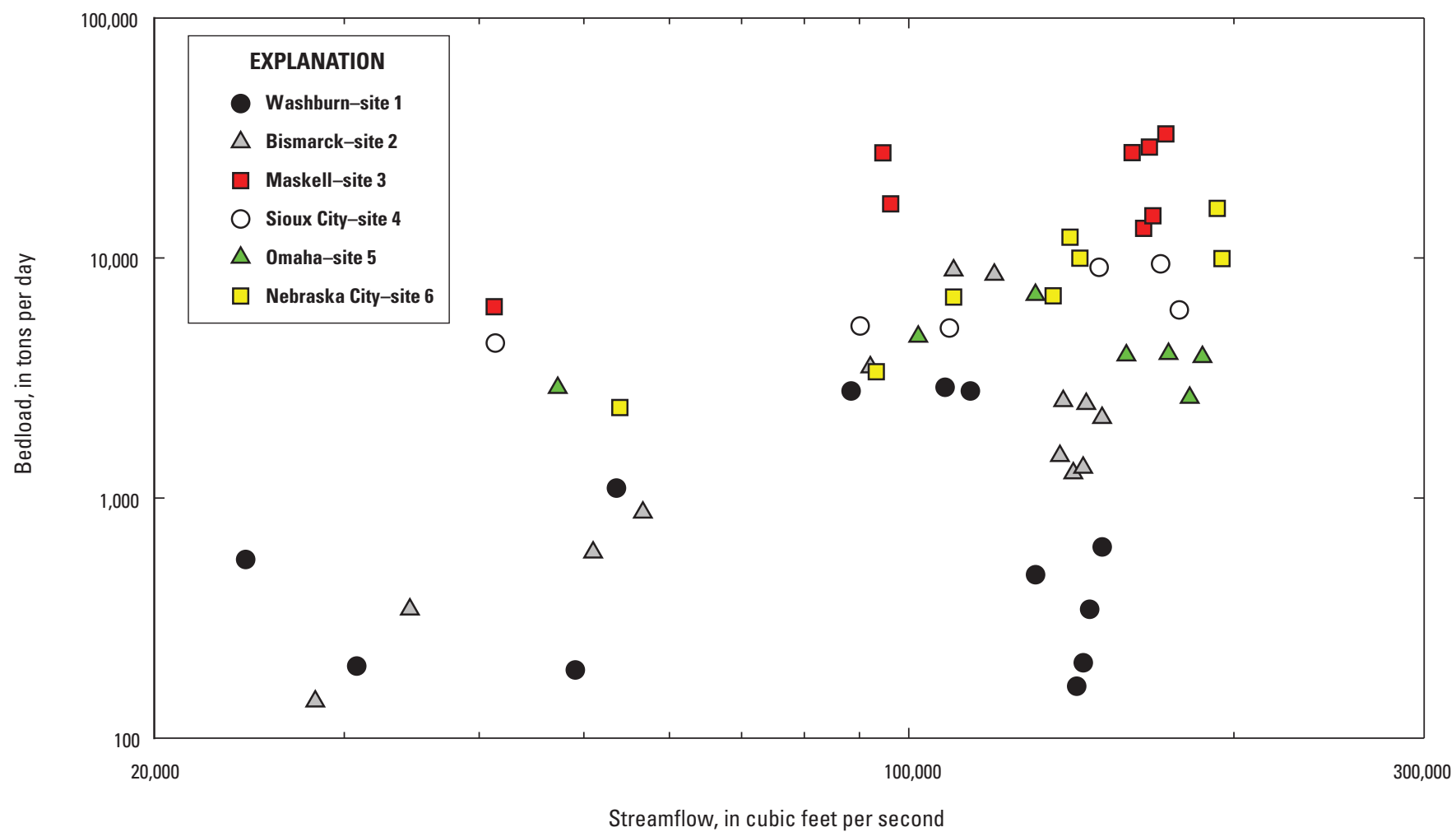

Figure 7. Measured bedload in relation to streamflow for samples collected at six sites on the Missouri River during the 2011 high-flow conditions. 
conditions at the measurement sites introduce the possibility of the Missouri River entering upper-flow regime hydraulic conditions, bathymetric data collected concurrently with some of the samples indicated that the bed of the river at measurement sites was mostly covered in dunes or dune forms during the measurement periods (Benjamin J. Dietsch, U.S. Geological Survey, written commun., 2012). If upper-flow regime conditions were occurring and causing the low measured bedload transport rates, it would also be expected that only the coarsest grains were remaining on the bed, but measurements made during the highest transport rates (presumably when dunes were present) also had the coarsest grain sizes.

A third potential explanation for the temporal pattern of measured bedload discharge rates is a change in sources of sediment over the course of the high-flow period (fig. 7). During average or bankfull streamflow conditions, upstream sediment delivery and the local bed and banks are the primary sources of sediment; however, when a river goes over bank, begins to scour its bed beyond the amplitude of dunes or islands, and banks begin to erode and unravel, the river may have access to additional sources of sediment. The 2011 event was unusual for both its magnitude at the sediment measurement sites, and also for its duration. The prolonged nature of the flood stressed the existing bank protection as well as the extensive system of levees along both reaches. Anecdotal observations by USGS personnel made in the lower segment of the Missouri River in November of 2011 indicated that substantial bank erosion occurred, in some cases eliminating much of the bank protection that existed before the flood and causing unraveling of the banks. In addition, numerous levees were known to have breached during the flood and deposition of thick sand deposits on flood plain areas immediately adjacent to banks and across point bars was documented in the reaches between Sioux City, Iowa and St. Joseph, Mo. (Jacobson, 2012). Thus, the distinct shifts in bedload transport may have been the result of formerly stable depositional features (islands, flood plain, and the river bed), destabilizing, unraveling, and liberating additional sediments that were untapped in the early weeks and months of the event. In the absence of additional scientific observations or reconnaissance of the geomorphic activity that occurred during the flood, this possibility also is inconclusive.

The grain-size distributions of the bedload transported past the sites in the middle segment of the Missouri River varied temporally in 2011 (fig. 6 and table 4). At sites 1 and 2 , grain sizes of the sediment in the bedload generally transitioned from fine- to more coarse-sized material throughout the event. Throughout the rise, peak, and early fall of the streamflow hydrograph, bedload was dominated by material ranging from 0.125 to $0.250 \mathrm{~mm}$ (note the log scale in figure 6). The samples collected on August 4 at site 1 and 2, which were the greatest measured bedloads at those sites, had larger proportions of coarser material ranging from 0.250 to $32 \mathrm{~mm}$ in size. Subsequent samples were dominated by material ranging from 0.250 to $0.500 \mathrm{~mm}$ at site 1 and from 0.250 to $1 \mathrm{~mm}$ at site 2. This coarsening of bedload particles, but reduction in streamflow as time passed further suggests the presence of sediment-supply limitations at sites 1 and 2 . At sites in the lower segment of the Missouri River, the range of grain sizes and changes in grain sizes in the bedload over time demonstrated a different pattern compared to the sites in the middle segment. At site 3, the grain-size distribution in the bedload was fairly consistent throughout the high-flow event, dominated by material ranging in size from 0.250 to $1 \mathrm{~mm}$ (fig. 6 and table 4). At sites 4-6, the change in grain-size distribution in the bedload was the opposite of what was observed at sites in the middle segment of the Missouri River, generally transitioning from coarser material to finer material throughout the event. At site 4, most of the bedload material ranged from 0.250 to $1 \mathrm{~mm}$, although a considerable portion of the bedload had material greater than $1 \mathrm{~mm}$ in samples collected on the rise, peak, and early fall of the streamflow hydrograph. Though this may be anomalous, visual inspections of those bedload samples suggested that pieces of shale were present, perhaps scoured from shale bedrock upstream. Although the physical properties of these shale pieces were not quantified, they likely were different than the dominant sands and gravels of the streambed. As a result, these shale pieces would have behaved differently and may have been more prone to incipient motion than the surrounding sands and gravels. Subsequent samples at site 4 also were dominated by bedload material ranging from 0.250 to $1 \mathrm{~mm}$, with more material ranging from 0.125 to $0.250 \mathrm{~mm}$ than previous samples, and little material greater than $1 \mathrm{~mm}$. Samples collected at site 5 indicated a similar pattern in grain-size change throughout the event, although the bedload did not contain appreciable amounts of material greater than $1 \mathrm{~mm}$ as was observed at site 4. Bedload samples collected at site 6 indicated a similar pattern of decreasing grain size throughout the event, although the distribution of sizes was different than observed at the other sites in that a large proportion of the bedload was composed of material ranging from 1 to $4 \mathrm{~mm}$ throughout most of the event (fig. 6 and table 4).

\section{Total Sediment Loads}

With the exception of site 3, the total-sediment load on the Missouri River was highest at the beginning of the high-flow event and decreased as streamflow decreased (fig. 8 and table 5). With the exception of the site 5 to site 6 reach of the lower segment, total-sediment load increased in the downstream direction. In the middle segment of the Missouri River, measured total-sediment load ranged from 2,320 (September 29) to 182,000 tons/d (June 16) at site 1 and from 3,190 (September 29) to 279,000 tons/d (June 9) at site 2. In the lower segment of the Missouri River, measured total-sediment load ranged from 50,600 (November 1) to 223,000 tons/d (July 1) at site 4; from 23,500 (October 31) to 403,000 tons/d (July 8) at site 5; and from 52,700 (November 3) to 273,000 tons/d (June 27) at site 6. The measured total-sediment was only computed for two samples at site 3 : 

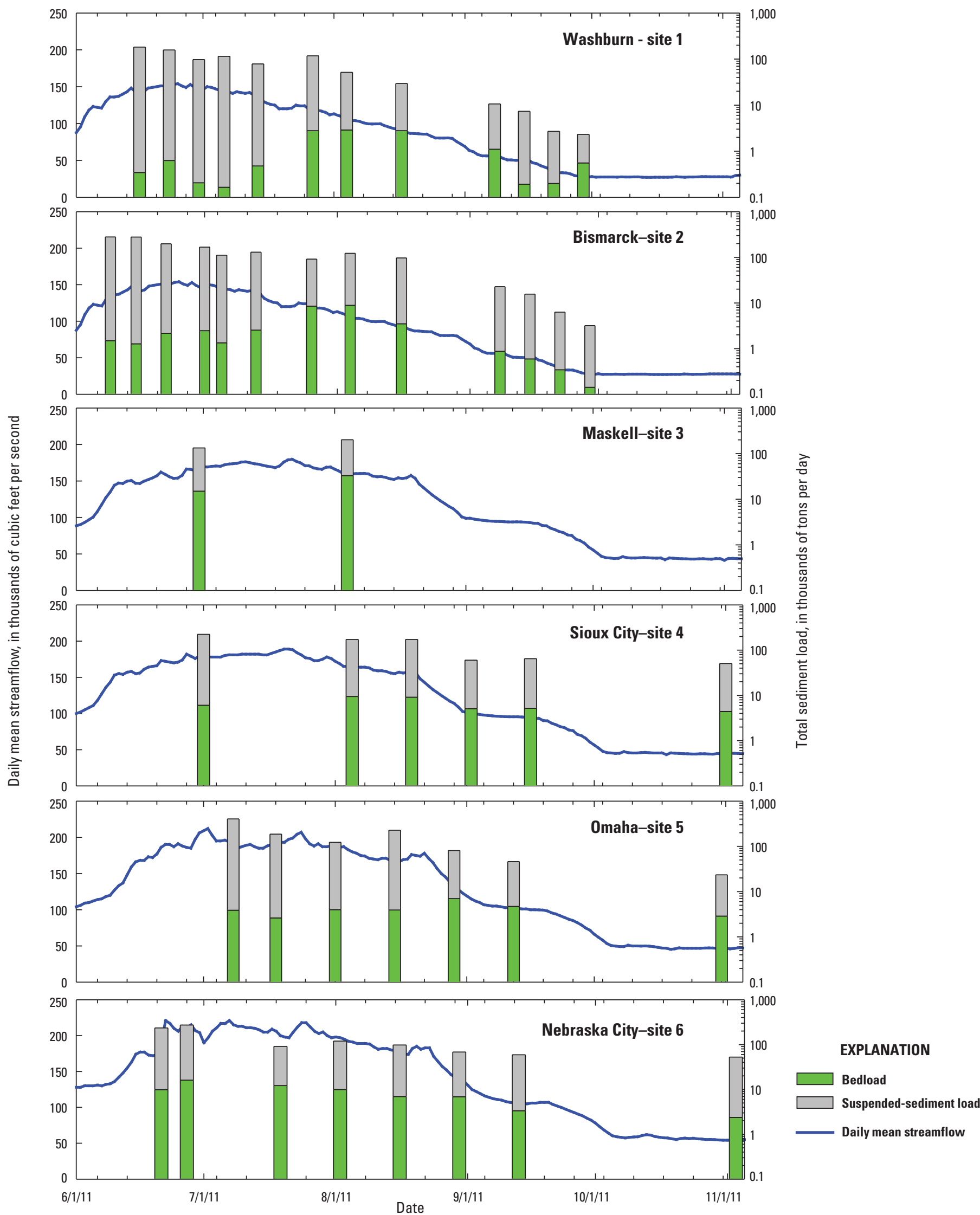

Figure 8. Time series of total sediment load and daily mean streamflow for six sites on the Missouri River during the 2011 high-flow conditions. 


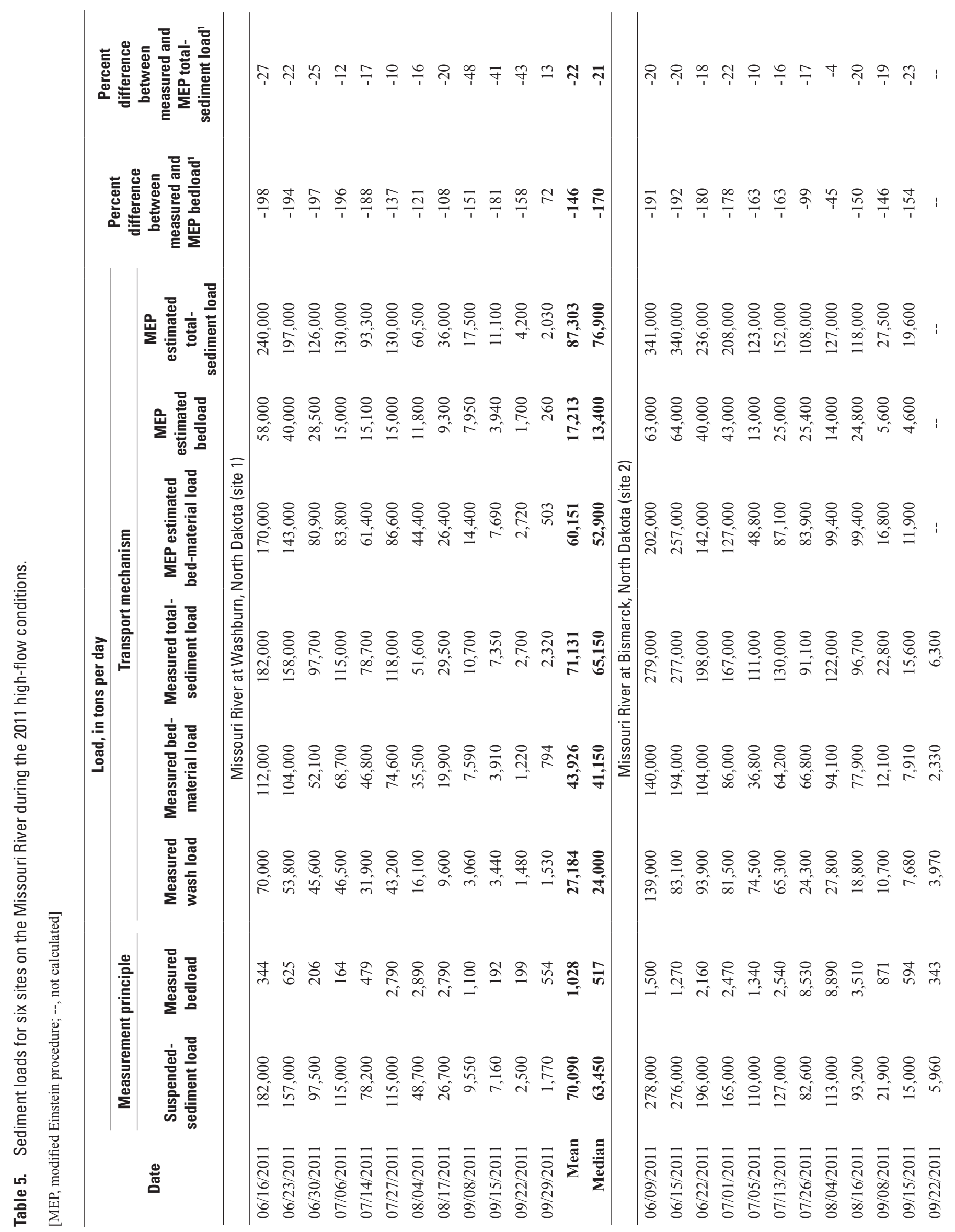




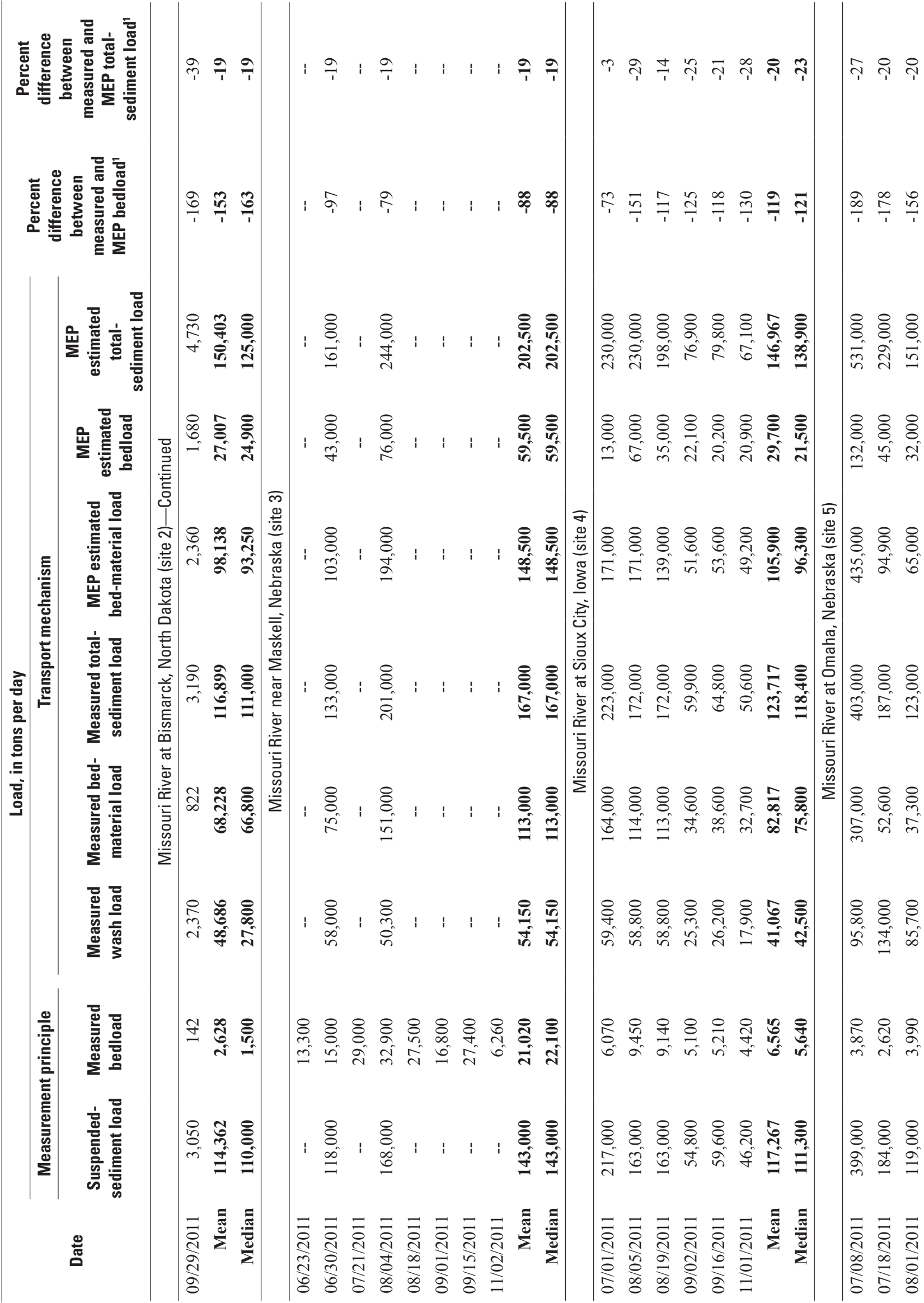




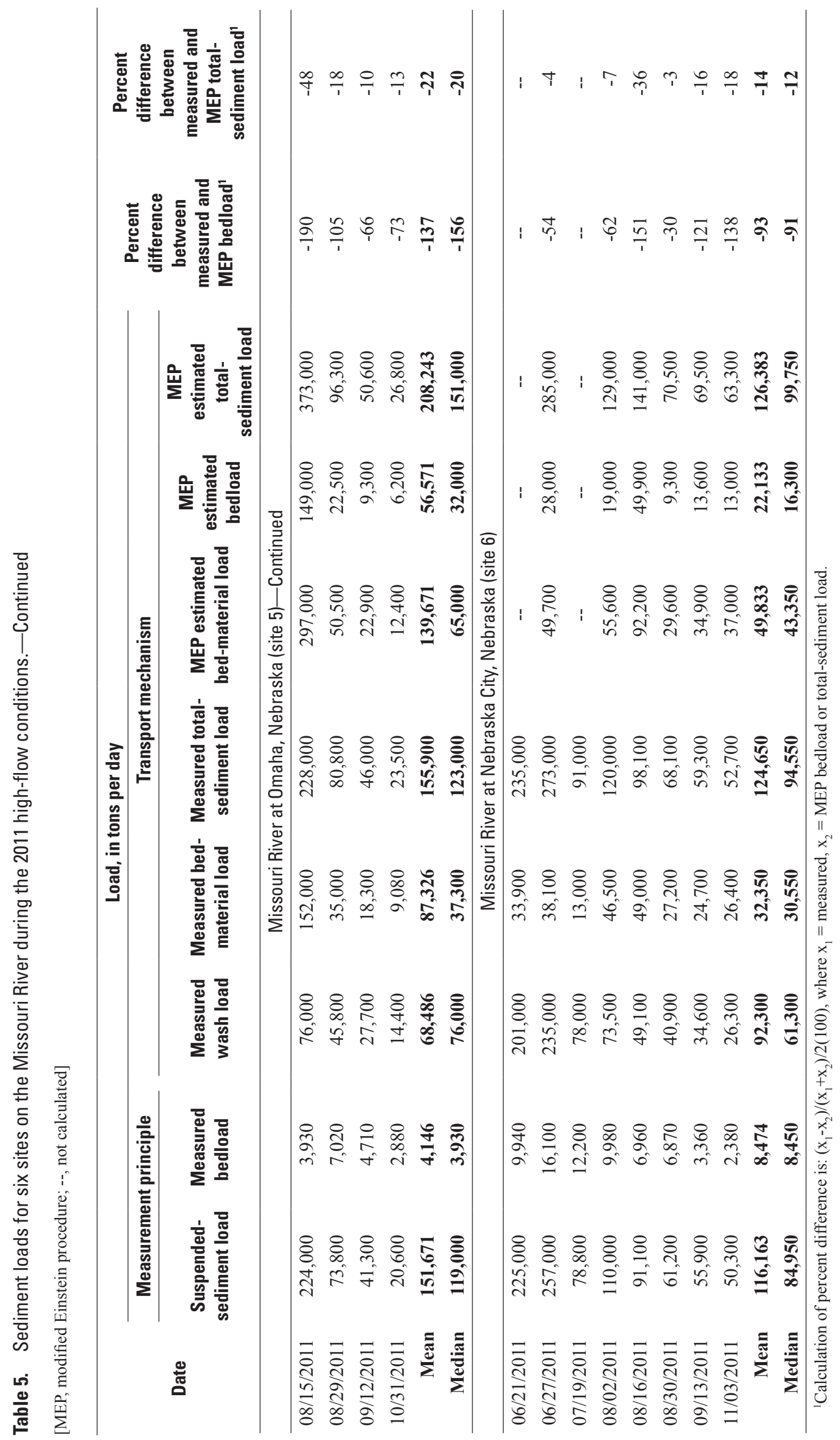


one on June 30 (133,000 tons/d) and one on August 4 (201,000 tons/d). The decrease in measured total-sediment load between sites 5 and site 6 was likely the result of either deposition between stations, the exclusion of measurements of sediment transport in the overbank area at site 6 , or both.

The total-sediment load was dominated by suspended sediment at all of the sites measured on the Missouri River in 2011. This suggests that measurements of suspended-sediment load alone characterized most of the sediment load in the Missouri River during 2011. In general, the percentage of total-sediment load that was bedload increased as the streamflow decreased, although this pattern was more prevalent at sites in the middle segment than those in the lower segment. The suspended-sediment load comprised an average of 93 percent of the total load, with the exception of site 3 , where the suspended-sediment load comprised only 72 percent of the total-sediment load (fig. 8; note the log scale). Although site 3 only had two values of total-sediment load for comparison, it is noteworthy that site 3 was the only site in the unchannelized reach in this study. It is possible, though inconclusive from these results, that the wider, meandering channel of site 3 created hydraulic conditions more favorable for bedload transport than the other sites. Although seven suspended-sediment samples were collected from site 3, suspended-sediment-load comparisons to the other sites supported that five of those seven samples became compromised with bed material, as mentioned earlier in the Suspended-Sediment Characteristics section. The five compromised samples had, on average, 280,000 tons/d, or 390 percent, more suspended-sediment load than the closest adjacent site (site 4). Of the two uncompromised samples, the suspended load at site 3 was 45,000 tons/d, or 20 percent less than that observed at site 4 . Some sediment deposition may have occurred between the two sites, but such a large magnitude is unlikely. In addition, the greater confinement of the channel in the channelized reach of site 4 as compared to the unchannelized reach of site 3 would tend to result in a transition from bedload to suspended load, thereby leading to an increased suspended-sediment load at site 4 in comparison to site 3 .

Although the suspended-sediment load and bedload clearly were differentiated by the mechanism by which they were sampled, further calculations were necessary to characterize the differences in the sediment-transport mechanisms. As stated previously, the wash load was classified as the portion of the suspended-sediment load consisting of grain sizes finer than that represented in the bed (table 2). More specifically, the fifth-percentile diameter of the bed-material grainsize distribution was used as the threshold for classifying the suspended-load components. Grain sizes finer than the threshold diameter were considered wash load. All other components of sediment load were part of the bed-material load. Using this definition, the wash load averaged 41 and 46 percent of the measured total-sediment load at sites 1 and 2, respectively (table 5). In the lower segment, the wash load averaged 36, 54, and 67 percent of the total measured sediment load at sites 4 , 5 , and 6 , respectively. The increased component of wash load in the downstream direction in the lower-segment sites may be related to increased sediment contributions from tributaries. These percentages also indicate that the bed-material load often comprised a majority of sediment being transported. It should be noted, however, that the depth-integrated suspended-sediment sampler was rarely lowered to the streambed, and often did not include the 0.5 to $2.0 \mathrm{ft}$ above the streambed. The suspended-sediment load may have contained more bed material than what was measured, but in the absence of a specialized analysis the effects of the suspended-sediment sampling technique cannot be quantified.

\section{Comparison of Bedload Estimation Methods}

Because of the difficulty in obtaining a high-quality bedload sample, the use of the modified-Einstein procedure (MEP) was explored as an alternative approach for estimating sediment load. Specifically, the BORAMEP model (U.S. Bureau of Reclamation, 2010) was utilized to estimate the bed-material load. This model relies on some overlap between the suspended-sediment grain-size distribution (table 3) and the bed-material grain-size distribution (table 6). Five percent overlap was used by default with 1-percent overlap used in some samples dominated by washload; however, three samples - one at site 2 and two at site 6 - had less than 1 percent overlap in grain size, and thus loads could not be estimated for those three samples. Again, the lack of overlap potentially is due to suspended-sediment sampling technique, but the effects cannot be quantified. In addition, all but two of the samples from site 3 were discarded because of presumed sampling errors already discussed. The MEP was performed on the remaining samples, and the resulting bed-material load estimates are shown in table 5. The total-sediment load was then estimated by adding the measured wash load to the estimated bed-material load (table 5). These load estimates are compared to the load measurements to evaluate the performance of the MEP model on samples collected at the six sites on the Missouri River in 2011.

The MEP-derived estimates of total-sediment load were similar to the measured total-sediment load (fig. $9 \mathrm{~A}$ and table 5). The MEP estimated total-sediment loads averaged 19 percent higher than the measured total-sediment loads, but the difference never exceeded 48 percent. Given the complexity inherent in sediment transport, model performance within the same order of magnitude was considered good; however, the comparability between the measured total-sediment load and the MEP estimated total-sediment load largely is an artifact of the predominance of suspended-sediment load in the samples. The MEP method for determining the total-sediment load essentially combines the measured suspended-sediment load (eq. 1) (less the wash load) with an estimate of bedload. Therefore, a better evaluation of the MEP performance would be to compare the MEP estimate of bedload to the measured bedload (eq. 2). The MEP estimated bedload was determined by subtracting the measured suspended-sediment load from 
Table 6. Grain sizes of bed-material samples for six sites on the Missouri River during the 2011 high-flow conditions.

[mm, millimeter]

\begin{tabular}{|c|c|c|c|c|c|c|c|c|c|}
\hline \multirow[b]{2}{*}{ Date } & \multicolumn{9}{|c|}{ Bed-material fall diameter (grain size) (percent in size range) } \\
\hline & $\begin{array}{c}0.062 \text { to } 0.125 \\
\mathrm{~mm}\end{array}$ & $\begin{array}{c}0.125 \text { to } 0.250 \\
\mathrm{~mm}\end{array}$ & $\begin{array}{c}0.250 \text { to } 0.500 \\
\mathrm{~mm}\end{array}$ & $\begin{array}{c}0.500 \text { to } 1 \\
\mathrm{~mm}\end{array}$ & $\begin{array}{c}1 \text { to } 2 \\
\mathrm{~mm}\end{array}$ & $\begin{array}{c}2 \text { to } 4 \\
\mathrm{~mm}\end{array}$ & $\begin{array}{c}4 \text { to } 8 \\
\mathrm{~mm}\end{array}$ & $\begin{array}{c}8 \text { to } 16 \\
\mathrm{~mm}\end{array}$ & $\begin{array}{c}16 \text { to } 32 \\
\mathrm{~mm}\end{array}$ \\
\hline \multicolumn{10}{|c|}{ Missouri River at Washburn, North Dakota (site 1) } \\
\hline $06 / 16 / 2011$ & 2 & 23 & 43 & 8 & 2 & 3 & 5 & 2 & 12 \\
\hline $06 / 23 / 2011$ & 6 & 48 & 38 & 7 & 1 & 0 & 0 & 0 & 0 \\
\hline $06 / 30 / 2011$ & 4 & 41 & 41 & 5 & 1 & 0 & 1 & 7 & 0 \\
\hline 07/06/2011 & 3 & 33 & 7 & 5 & 1 & 2 & 1 & 14 & 34 \\
\hline $07 / 14 / 2011$ & 1 & 51 & 15 & 3 & 2 & 2 & 6 & 11 & 9 \\
\hline $07 / 27 / 2011$ & 2 & 54 & 27 & 3 & 2 & 1 & 4 & 4 & 3 \\
\hline 08/04/2011 & 1 & 38 & 59 & 1 & 0 & 0 & 1 & 0 & 0 \\
\hline 08/17/2011 & 3 & 39 & 52 & 4 & 0 & 0 & 1 & 1 & 0 \\
\hline 09/08/2011 & 8 & 40 & 45 & 5 & 0 & 1 & 0 & 0 & 0 \\
\hline $09 / 15 / 2011$ & 5 & 70 & 24 & 1 & 0 & 0 & 0 & 0 & 0 \\
\hline $09 / 22 / 2011$ & 9 & 74 & 14 & 1 & 0 & 0 & 0 & 0 & 0 \\
\hline 09/29/2011 & 2 & 44 & 25 & 4 & 1 & 2 & 5 & 7 & 10 \\
\hline Mean & 4 & 46 & 33 & 4 & 1 & 1 & 2 & 4 & 6 \\
\hline Median & 3 & 43 & 33 & 4 & 1 & 1 & 1 & 2 & $\mathbf{0}$ \\
\hline \multicolumn{10}{|c|}{ Missouri River at Bismarck, North Dakota (site 2) } \\
\hline 06/09/2011 & 2 & 55 & 41 & 1 & 1 & 0 & 0 & 0 & 0 \\
\hline $06 / 15 / 2011$ & 2 & 42 & 54 & 2 & 0 & 0 & 0 & 0 & 0 \\
\hline $06 / 22 / 2011$ & 1 & 26 & 65 & 6 & 0 & 1 & 1 & 0 & 0 \\
\hline 07/01/2011 & 0 & 17 & 56 & 25 & 2 & 0 & 0 & 0 & 0 \\
\hline $07 / 05 / 2011$ & 0 & 10 & 46 & 33 & 4 & 0 & 2 & 0 & 5 \\
\hline 07/13/2011 & 0 & 14 & 42 & 34 & 7 & 2 & 1 & 0 & 0 \\
\hline $07 / 26 / 2011$ & 1 & 18 & 35 & 30 & 9 & 4 & 3 & 0 & 0 \\
\hline $08 / 04 / 2011$ & 1 & 18 & 39 & 26 & 6 & 1 & 2 & 0 & 7 \\
\hline 08/16/2011 & 1 & 36 & 34 & 14 & 6 & 4 & 3 & 2 & 0 \\
\hline 09/08/2011 & 3 & 49 & 24 & 9 & 6 & 4 & 1 & 4 & 0 \\
\hline $09 / 15 / 2011$ & 3 & 43 & 25 & 15 & 6 & 4 & 4 & 0 & 0 \\
\hline $09 / 22 / 2011$ & 4 & 63 & 20 & 7 & 2 & 2 & 2 & 0 & 0 \\
\hline 09/29/2011 & 2 & 50 & 29 & 13 & 4 & 2 & 0 & 0 & 0 \\
\hline Mean & 2 & 34 & 39 & 17 & 4 & 2 & 1 & 0 & 1 \\
\hline Median & 1 & 36 & 39 & 14 & 4 & 2 & 1 & 0 & $\mathbf{0}$ \\
\hline \multicolumn{10}{|c|}{ Missouri River near Maskell, Nebraska (site 3) } \\
\hline $06 / 23 / 2011$ & 0 & 19 & 74 & 7 & 0 & 0 & 0 & 0 & 0 \\
\hline $06 / 30 / 2011$ & 1 & 32 & 58 & 8 & 1 & 0 & 0 & 0 & 0 \\
\hline $07 / 21 / 2011$ & 2 & 36 & 44 & 16 & 2 & 0 & 0 & 0 & 0 \\
\hline 08/04/2011 & 1 & 24 & 45 & 22 & 6 & 2 & 0 & 0 & 0 \\
\hline 08/18/2011 & 1 & 36 & 54 & 6 & 1 & 1 & 1 & 0 & 0 \\
\hline 09/01/2011 & 0 & 17 & 50 & 22 & 4 & 1 & 1 & 5 & 0 \\
\hline 09/15/2011 & 0 & 22 & 54 & 20 & 2 & 1 & 1 & 0 & 0 \\
\hline $11 / 02 / 2011$ & 0 & 12 & 64 & 21 & 2 & 0 & 0 & 1 & 0 \\
\hline Mean & 1 & 25 & 55 & 15 & 2 & 1 & $\mathbf{0}$ & 1 & 0 \\
\hline Median & 1 & 23 & 54 & 18 & 2 & 1 & $\mathbf{0}$ & 0 & $\mathbf{0}$ \\
\hline
\end{tabular}


Table 6. Grain sizes of bed-material samples for six sites on the Missouri River during the 2011 high-flow conditions.Continued

[mm, millimeter]

\begin{tabular}{|c|c|c|c|c|c|c|c|c|c|}
\hline \multirow[b]{2}{*}{ Date } & \multicolumn{9}{|c|}{ Bed-material fall diameter (grain size) (percent in size range) } \\
\hline & $\begin{array}{c}0.062 \text { to } 0.125 \\
\mathrm{~mm}\end{array}$ & $\begin{array}{c}0.125 \text { to } 0.250 \\
\mathrm{~mm}\end{array}$ & $\begin{array}{c}0.250 \text { to } 0.500 \\
\mathrm{~mm}\end{array}$ & $\begin{array}{c}0.500 \text { to } 1 \\
\mathrm{~mm}\end{array}$ & $\begin{array}{c}1 \text { to } 2 \\
\mathrm{~mm}\end{array}$ & $\begin{array}{c}2 \text { to } 4 \\
\mathrm{~mm}\end{array}$ & $\begin{array}{c}4 \text { to } 8 \\
\mathrm{~mm}\end{array}$ & $\begin{array}{c}8 \text { to } 16 \\
\mathrm{~mm}\end{array}$ & $\begin{array}{c}16 \text { to } 32 \\
\mathrm{~mm}\end{array}$ \\
\hline \multicolumn{10}{|c|}{ Missouri River at Sioux City, lowa (site 4) } \\
\hline 07/01/2011 & 0 & 47 & 36 & 16 & 0 & 0 & 0 & 0 & 0 \\
\hline 08/05/2011 & 0 & 34 & 37 & 19 & 7 & 1 & 1 & 1 & 0 \\
\hline 08/19/2011 & 1 & 31 & 35 & 6 & 5 & 6 & 9 & 5 & 2 \\
\hline 09/02/2011 & 1 & 31 & 42 & 16 & 3 & 1 & 1 & 0 & 5 \\
\hline 09/16/2011 & 1 & 31 & 64 & 2 & 1 & 1 & 0 & 0 & 0 \\
\hline $11 / 01 / 2011$ & 0 & 14 & 74 & 9 & 2 & 1 & 0 & 0 & 0 \\
\hline Mean & 1 & 31 & 48 & 11 & 3 & 2 & 2 & 1 & 1 \\
\hline Median & 1 & 31 & 40 & 13 & 3 & 1 & 1 & $\mathbf{0}$ & $\mathbf{0}$ \\
\hline \multicolumn{10}{|c|}{ Missouri River at Omaha, Nebraska (site 5) } \\
\hline 07/08/2011 & 3 & 16 & 56 & 18 & 3 & 1 & 2 & 0 & 0 \\
\hline 08/01/2011 & 0 & 5 & 56 & 30 & 7 & 2 & 0 & 0 & 0 \\
\hline $08 / 15 / 2011$ & 0 & 7 & 63 & 27 & 3 & 0 & 0 & 0 & 0 \\
\hline $09 / 12 / 2011$ & 0 & 22 & 70 & 7 & 1 & 0 & 0 & 0 & 0 \\
\hline $10 / 31 / 2011$ & 0 & 9 & 58 & 15 & 5 & 4 & 2 & 7 & 0 \\
\hline Mean & 1 & 12 & 61 & 19 & 4 & 1 & 1 & 1 & $\mathbf{0}$ \\
\hline Median & $\mathbf{0}$ & 9 & 58 & 18 & 3 & 1 & $\mathbf{0}$ & $\mathbf{0}$ & $\mathbf{0}$ \\
\hline \multicolumn{10}{|c|}{ Missouri River at Nebraska City, Nebraska (site 6) } \\
\hline $06 / 28 / 2011$ & 0 & 3 & 37 & 52 & 4 & 1 & 2 & 1 & 0 \\
\hline 07/19/2011 & 0 & 4 & 24 & 33 & 20 & 13 & 6 & 0 & 0 \\
\hline 08/02/2011 & 0 & 9 & 31 & 31 & 17 & 7 & 3 & 2 & 0 \\
\hline 08/16/2011 & 1 & 17 & 30 & 33 & 12 & 5 & 2 & 0 & 0 \\
\hline 09/13/2011 & 3 & 51 & 26 & 13 & 4 & 2 & 1 & 0 & 0 \\
\hline $11 / 03 / 2011$ & 5 & 44 & 40 & 2 & 0 & 0 & 0 & 0 & 0 \\
\hline Mean & 2 & 21 & 31 & 27 & 10 & 5 & 2 & 1 & 0 \\
\hline Median & 1 & 13 & 31 & 32 & 8 & 4 & 2 & $\mathbf{0}$ & $\mathbf{0}$ \\
\hline
\end{tabular}



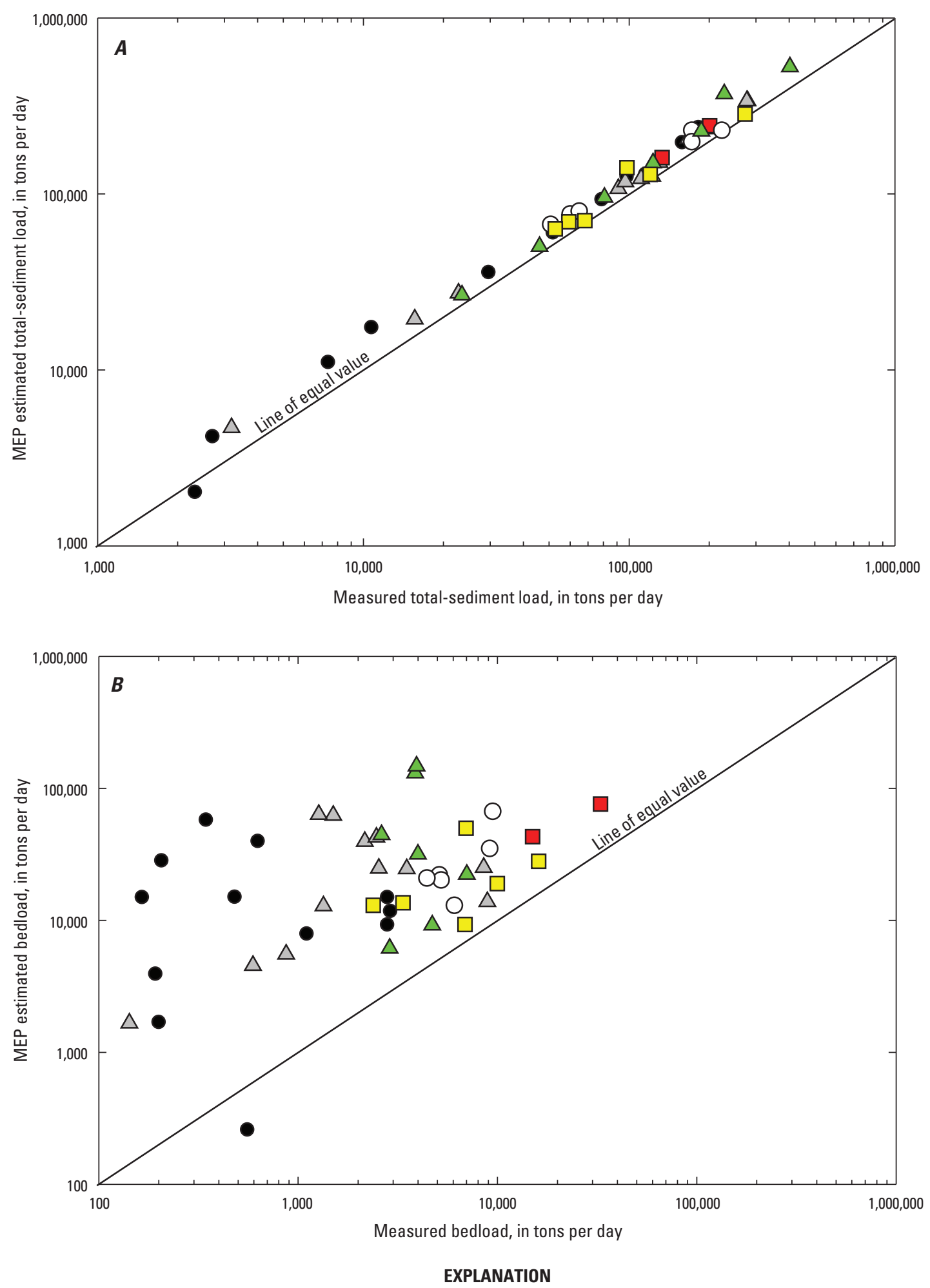

- Washburn-site 1

Sioux City-site 4

$\triangle$ Bismarck-site 2

$\triangle$ Omaha-site 5

$\square$ Maskell-site 3

$\square$ Nebraska City-site 6

Figure 9. Sediment loads estimated by the modified-Einstein procedure (MEP) compared to measured: $A$, total-sediment load; and $B$, bedload. 
the MEP estimated total-sediment load (table 5). A comparison of the estimated bedload to the measured bedload indicates that the MEP-derived estimate was considerably higher in magnitude (fig. $9 B$ and table 5). The average difference indicated that the MEP estimated bedload was 133 percent greater than that of the measured bedload, with one estimate 198 percent greater than the measured bedload. The differences tended to be highest near the peak of the flood, and steadily decreased with the recession of the streamflow hydrograph.

There are several potential explanations for MEP estimated bedloads being systematically higher than the measured bedloads. Whereas the physical-bedload samplers measured bedload in the first 3 inches above the streambed, the MEP estimated bedload includes the entire zone left unsampled by the suspended-sediment samplers, which was estimated to be 6 inches in the BORAMEP simulations. Therefore, estimated bedloads double that of the measured bedloads might not be unreasonable. This may explain some of the positive differences, though not all. Another potential explanation for the differences is the potential for the measured suspended-sediment loads to be biased low because of the exclusion of the bottom 0.5 to $2.0 \mathrm{ft}$ of the water column. Thus, subtraction of the total-measured-suspended load would result in the estimate of bedload being proportionally larger. The performance of the MEP may also be compromised by the extreme hydraulic conditions of the Missouri River in 2011, particularly if hydraulic conditions entered an upper-flow regime at any time during sampling. This might explain the reduction in the overestimate as the flood receded. The extreme hydraulic conditions may also have affected the performance of the physical samplers, though it was more likely to lead to overestimates in measured bedload than underestimates (because of the potential for dredging the streambed). Finally, the consistently higher estimates may also suggest that sediment transport was supplylimited. The MEP assumes that sediment transport is limited by the energy to move it. If sediment transport were actually being limited instead by the sediment supply, this would cause a systematic overestimation by the MEP.

Although the methods described in this report provide reasonable estimates of the bedload, a level of uncertainty still exists as to the true value of the bedload at the six sites. Another potential resource for determining bedload is the use of time-sequenced bathymetric data (Nittrouer and others, 2008; McElroy and Mohrig, 2009; Abraham and others, 2011). Although the use of this method was outside of the scope of this report, the time-sequenced bathymetric data were collected concurrently with a subset of the samples in the lower segment in anticipation for future analyses that will assist with the understanding of bedload transport in the Missouri River.

\section{Summary}

During 2011, many tributaries in the Missouri River Basin experienced near-record peak streamflow and caused flood damage to many communities along much of the Missouri River from Montana to the confluence with the Mississippi River. The large runoff event in 2011 provided an opportunity to examine characteristics of sediment transport in the Missouri River at high-magnitude discharges and over a long duration. The purpose of this report is to describe sediment characteristics during the 2011 high-flow conditions at six selected sites on the Missouri River, two in the middle region of the basin between Lake Sakakawea and Lake Oahe in North Dakota, and four downstream from Gavins Point Dam along the Nebraska-South Dakota, and Nebraska-Iowa borders. Sediment samples were collected from June to November at various intervals among the six sites.

A wider range in suspended-sediment concentration was observed in the middle segment of the Missouri River compared to sites in the lower segment. More samples were collected at a wider range of streamflows at the sites in the middle segment compared to sites in the lower segment, and these included samples as flows were increasing, which often have the highest concentrations. Median suspended-sediment concentrations in the middle segment of the Missouri River were 194 milligrams per liter at site 1 and 338 milligrams per liter at site 2. In the lower segment of the Missouri River, median suspended-sediment concentration ranged from 236 milligrams per liter (site 6) to 373 milligrams per liter (site 4).

Suspended-sediment concentration varied with time during the high-flow conditions at the six sites on the Missouri River in 2011. In the middle segment of the Missouri River, suspended-sediment concentrations increased and peaked as flows increased and started to plateau, but while flows were still high and steady, suspended-sediment concentrations decreased and suspended-sediment grain sizes coarsened, indicating the decrease possibly was related to fine-sediment supply limitations. Three samples collected in July and August at sites 1 and 2 indicated subtle increases in suspended-sediment concentration as well as a coarser distribution of grain size than most of the other samples. The change in suspended-sediment characteristics for these three samples may be the result of channel bank or bed erosional processes in the Missouri River channel because a coincident increase in streamflow from the upstream tributary (Knife River) was not observed.

Measured bedload transport rates in the lower segment of the Missouri River (sites 3 to 6), where sand supplies from the banks and bed of the unchannelized reach and tributaries would be expected to be greater, were consistently higher than those in the middle segment (sites 1 and 2) during the highflow conditions in 2011. The median bedload transport rate measured at site 1 was 517 tons per day. The median bedload transport rate at site 2 was 1,500 tons per day. Measured bedload transport rates were highest at site 3 , then decreased downstream to site 5 , then increased at site 6 . The median bedload transport rate for site 3 was 22,100 tons per day and ranged from 6,260 to 32,900 tons per day. Median bedload transport rates at sites downstream from site 3 were 5,640 tons per day at site $4 ; 3,930$ tons per day at site 5 ; and 8,450 tons per day at site 6 . Measured bedload varied with time during 
the high-flow conditions at the six sites on the Missouri River in 2011. At the two sites in the middle segment of the Missouri River, the greatest bedload was measured during the recession of the streamflow hydrograph. A similar pattern was observed at sites 3-5 in the lower segment of the Missouri River, where the greatest bedload was measured later in the event on the fall of the streamflow hydrograph, although the change in bedload was not as dramatic as observed at the sites in middle segment of the Missouri River.

With the exception of site 3, the total-sediment load on the Missouri River was highest at the beginning of the highflow event and decreased as streamflow decreased. In the middle segment of the Missouri River, measured total-sediment load ranged from 2,320 (September 29) to 182,000 tons per day (June 16) at site 1 and from 3,190 (September 29) to 279,000 tons per day (June 9) at site 2. In the lower segment of the Missouri River, measured total-sediment load ranged from 50,600 (November 1) to 223,000 tons per day (July 1) at site 4; from 23,500 (October 31) to 403,000 tons per day (July 8) at site 5; and from 52,700 (November 3) to 273,000 tons per day (June 27) at site 6. The measured total sediment was only computed for two samples at site 3 : one on June 30 (133,000 tons per day) and one on August 4 (201,000 tons per day).

The total-sediment load was dominated by suspended sediment at all of the sites measured on the Missouri River in 2011. This suggests that measurements of suspended-sediment load alone characterized most of the sediment load in the Missouri River during 2011. In general, the percentage of totalsediment load that was bedload increased as the streamflow decreased, although this pattern was more prevalent at sites in the middle segment than those in the lower segment. The suspended-sediment load comprised an average of 93 percent of the total load, with the exception of site 3 , where the suspended-sediment load comprised only 72 percent of the total-sediment load.

\section{References Cited}

Abraham, David, Kuhnle, R.A., and Odgaard, A.J., 2011, Validation of bed-load transport measurements with timesequenced bathymetric data: Journal of Hydraulic Engineering, v. 137 , no. 7 , p. $723-728$.

Biedenharn, D.S., Soileau, R.S., Hubbard, L.C., Hoffman, P.H., Thorne, C.R., Bromley, C.C., and Watson, C.C., 2001, Missouri River-Fort Peck Dam to Ponca State Park geomorphological assessment related to bank stabilization: U.S. Army Corps of Engineers, Omaha District Paper 74, 136 p.

Chen, A.H., Rus, D.L., and Stanton, C.P., 1999, Trends in channel gradation in Nebraska streams: U.S. Geological Survey Water-Resources Investigations Report 99-4103, 29 p., 15 apps., 1 pl.
Church, M., 2006, Bed material transport and the morphology of alluvial river channels: Annual Reviews in Earth and Planetary Science, v. 34, p. 325-354.

Colby, B.R., and Hembree, C.H., 1955, Computation of total sediment discharge, Niobrara River near Cody, Nebr.: U.S. Geological Survey Water-Supply Paper 1357, 187 p.

Colby, B.R., and Hubbell, D.W., 1967, Simplified methods for computing total sediment discharge with the Modified Einstein Procedure: U.S. Geological Survey Water-Supply Paper 1593, $17 \mathrm{p}$.

Davis, B.E., 2005, A guide to the proper selection and use of federally approved sediment and water-quality samplers: U.S. Geological Survey, Open-File Report 2005-1087, 20 p.

Edwards, T.K., and Glysson, G.D., 1999, Field methods for measurement of fluvial sediment: U.S. Geological Survey Techniques of Water-Resources Investigations, book 3 , chap. C2, 89 p.

Einstein, H.A., 1950, The bedload function for sediment transportation in open channel flows: U.S. Department of Agriculture Technical Bulletin 1026, $70 \mathrm{p}$.

Elliott, C.M., and Jacobson, R.B., 2006, Geomorphic classification and assessment of channel dynamics in the Missouri National Recreation River, South Dakota and Nebraska: U.S. Geological Survey Scientific Investigations Report 2006-5313, 66 p.

Eschner, T.R., Hadley, R.F., and Crowley, K.D., 1983, Hydrologic and morphologic changes in channels of the Platte River Basin in Colorado, Wyoming, and Nebraska-A historical perspective: U.S. Geological Survey Professional Paper 1277-A, 39 p.

Friedman, J.M., Osterkamp, W.R., Scott, M.L., and Auble, G.T., 1998, Downstream effects of dams on channel geometry and bottomland vegetation-Regional patterns in the Great Plains: Wetlands, v. 18, p. 619-633.

Gaeuman, D., and Jacobson, R.B., 2007, Field assessment of alternative bed-load transport estimators: Journal of Hydraulic Engineering, v. 133, p. 1,319-1,328.

Grigg, N., McCarthy, C., Lawrence, B., Ockerman, D., 2012, Review of the regulation of the Missouri River main stem reservoir system during the flood of 2011: Missouri River Independent Review Panel report to the U.S. Army Corps of Engineers, Omaha District, 93 p.

Guy, H.P., 1969, Laboratory theory and methods for sediment analysis: U.S. Geological Survey Techniques of WaterResources Investigations Reports, book 5, chap. C1, 58 p. 
Heimann, D.C., Rasmussen, P.P., Cline, T.L., Pigue, L.M., and Wagner, H.R., 2010, Characteristics of sediment data and annual suspended-sediment loads and yields for selected lower Missouri River main stem and tributary stations, 1976-2008: U.S. Geological Survey Data Series Report 530, $58 \mathrm{p}$.

Helsel, D.R., and Hirsch, R.M., 1992, Statistical methods in water resources: Amsterdam, Elsevier Science Publishers, $529 \mathrm{p}$.

Jacobson, R.B., Blevins, D.W., and Bitner, C.J., 2009, Sediment regime constraints on river restoration-An example from the lower Missouri River: Geological Society of America Special Paper 451, p. 1-22.

Jacobson, R.B., 2012, Sand deposited on flood plains by the 2011 lower Missouri River Flood-A regional remotesensing assessment, in Program with Abstracts of the 2012 Missouri River Natural Resources Conference and BiOP Forum, Pierre, South Dakota: Missouri River Natural Resources Committee, p. 18.

Julien, P.Y., 2010, Erosion and sedimentation, (2d ed.): New York, Cambridge University Press, 371 p.

McElroy, Brandon, and Mohrig, David, 2009, Nature of deformation of sandy bed forms: Journal of Geophysical Research, v. 114, F00A04, accessed June 1, 2010, at http:// onlinelibrary.wiley.com/doi/10.1029/2008JF001220/full

Mueller, D.S., and Wagner, C.R., 2009, Measuring discharge with acoustic Doppler current profilers from a moving boat: U.S. Geological Survey Techniques and Methods, book 3, chap. A22, 73 p.
National Research Council, 2002, The Missouri River ecosystem-Exploring the prospects for recovery: Washington, D.C., National Academies Press, 176 p.

Nittrouer, J.A., Allison, M.A., and Campanella, Richard, 2008, Bedform transport rates for the lowermost Mississippi River: Journal of Geophysical Research, v. 113, F03004, accessed June 1, 2010, at http://onlinelibrary.wiley.com/ doi/10.1029/2007JF000795/pdf.

Porterfield, George, 1972, Computation of fluvial-sediment discharge: U.S. Geological Survey Techniques of WaterResources Investigations, book 3, chap. C3, 66 p.

Schmidt, J.C., and Wilcock, P.R., 2008, Metrics for assessing the downstream effects of dams: Water Resources Research, v. 44, W04404, accessed June 1, 2010, at http://www.agu. org/journals/wr/wr0804/2006WR005092/2006WR005092. $p d f$.

Shields, F.D., Simon, A., and Steffen, L.J., 2000, Reservoir effects on downstream river channel migration: Environmental Conservation, v. 27, p. 54-66.

Topping, D.J., Rubin, D.M., and Vierra, L.E., Jr., 2000, Colorado River sediment transport 1-Natural sediment supply limitation and the influence of Glen Canyon Dam: Water Resources Research, v. 36, p. 515-542.

van Rijn, L.C., 1984, Sediment transport, part III-Bed forms and alluvial roughness: Journal of Hydraulic Engineering, v. 110 , no. 12 , p. $1,733-1,754$.

U.S. Bureau of Reclamation, 2010, BORAMEP-Bureau of reclamation automated modified Einstein procedure: accessed June 1, 2010, at http://www.usbr.gov/pmts/ sediment/model/boramep/index.html.

Williams, G.P., and Wolman, M.G., 1984, Downstream effects of dams on alluvial rivers: U.S. Geological Survey Professional Paper 1286, 83 p. 
Publishing support provided by: Rolla Publishing Service Center

For more information concerning this publication, contact: Director, USGS North Dakota Water Science Center 821 East Interstate Avenue Bismarck, North Dakota 58503

(701) 250-7400

Or visit the North Dakota Water Science Center Web site at: http://nd.water.usgs.gov/ 
Back cover. Top photograph: Confluence of the spillway outflow from Garrison Dam, North Dakota, (flowing in from the left of the photograph) and the outflow from the tailraces of dam, June 23, 2011 (photograph by Joel M.Galloway, U.S. Geological Survey).

Bottom photograph: Missouri River on the north side of Bismarck, North Dakota, June 23, 2011 (photograph by Joel M. Galloway, U.S. Geological Survey). 


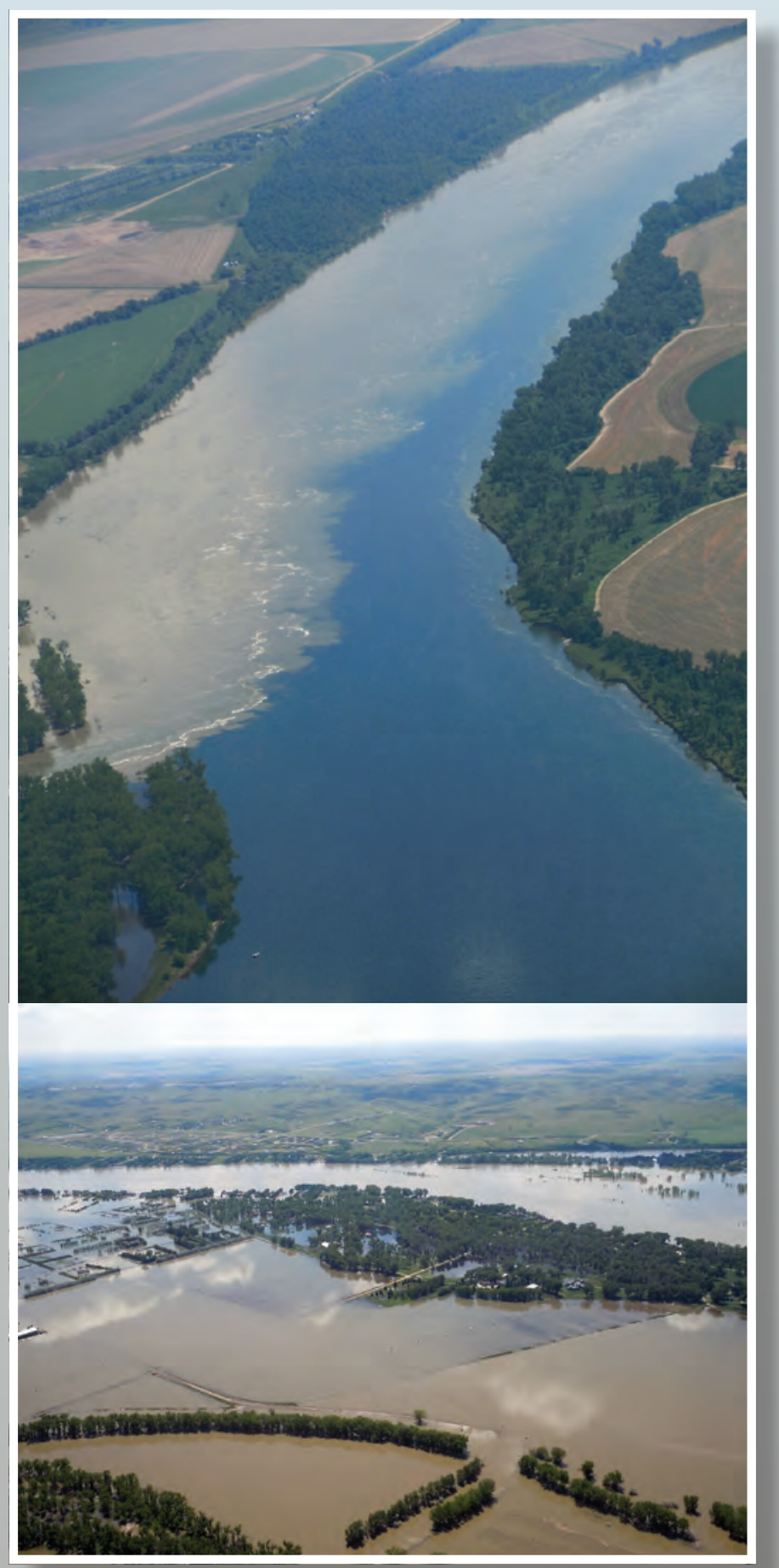

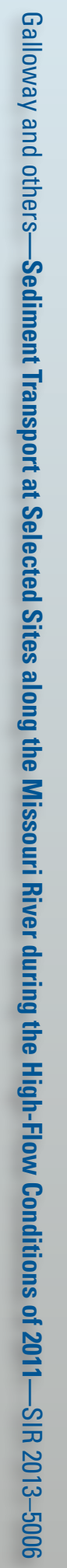

